\title{
DETERMINING OPTIMAL DRIP-IRRIGATION VOLUMES AFTER WETTING FOR MULCHED DRY-SEEDED COTTON (GOSSYPIUM HIRSUTUM L.) DURING THE SEEDLING STAGE USING HYDRUS-3D
}

\author{
SHAN, Y. Y..$^{1 *}$ - WANG, Q. J. ${ }^{1}-$ WANG, C. X. ${ }^{2}-$ SU, L. J. ${ }^{1}-$ DONG, W. C. ${ }^{3}-$ ZHANG, J. H. ${ }^{1}-$ \\ CAO, L. ${ }^{4}$ \\ ${ }^{I}$ State Key Laboratory of Eco-hydraulics in Northwest Arid Region of China, Xi'an University \\ of Technology, Xi'an 710048, China \\ ${ }^{2}$ College of Water and Architectural Engineering, Shihezi University, Shihezi 832033, China \\ ${ }^{3}$ College of Water Conservancy and Architecture, Northeast Agricultural University, Harbin \\ 150030, China
}

${ }^{4}$ Shaanxi Fengxi Xincheng Investment Development Co., Ltd, Xi'an 710048, China

*Corresponding author

e-mail: syy031@126.com; phone: +86-29-8231-2942

(Received 29 $9^{\text {th }}$ Mar 2021; accepted $19^{\text {th }}$ Jul 2021)

\begin{abstract}
Cotton (Gossypium hirsutum L.) is an important cash crop in the Xinjiang Autonomous Region of China where agricultural development is severely hampered by the scarcity of water resources and increasing soil salinity. We developed a new method of establishing cotton crops to maintain crop yields while reducing water use and suppressing salinity. The method consists of dry seeding after wetting with drip irrigation, without the traditional winter or spring irrigation. We verified that the HYDRUS-3D software package could successfully simulate the distribution of water and salinity at the seedling stage in 2009 and used it to determine the irrigation volumes during the seedling stage in 2010. The observed and simulated results were in accordance, and soil salinity did not exceed the salinity threshold in the root zone, indicating that HYDRUS-3D could accurately simulate water and salt transport and was useful for designing appropriate irrigation regimes. A double drip line with single mulch and a low emitter discharge should be applied in dry seeding and after wetted under moderate soil salinity. In addition, in order to help local agricultural production, we chose some impact factors (emitter spacing, emitter discharge and salinity content) based on the current local situation, evaluated the factors' effects on water and salinity distribution, irrigation uniformity (Christiansen uniformity coefficient, $C U$ ) and leaching rate $\left(L_{r}\right)$, in order to determine the optimal irrigation volume at the seedling stage using by HYDRUS-3D.

Keywords: cash crop, water-saving technology, water and salt transport, salinity threshold, computer software model
\end{abstract}

\section{Introduction}

Xinjiang has the largest area of cotton (Gossypium hirsutum L.) production in China, where cotton is an important economic crop. It is classified as a salt-tolerant crop, but its tolerance is both limited and variable at different growth stages (Sharif et al., 2019; Long et al., 2019). Different growth stages of cotton have salinity thresholds, above which growth is adversely affected. Jia et al. (1987) reported that cotton growth was seriously suppressed at a salinity of $5 \mathrm{~g} \mathrm{~kg}^{-1}$. Sun et al. (2009a) reported that thresholds $>4.2$ and $>3.3 \mathrm{~g} \mathrm{~kg}^{-1}$ at depths of $20 \mathrm{~cm}$ and $40 \mathrm{~cm}$, respectively, during the seedling stage had an impact on cotton yield. Dong et al. (2009) found that seedling emergence was $40 \%$ and seedling survival rate was $30 \%$ at salinities $>4 \mathrm{~g} \mathrm{~kg}^{-1}$ in a 
coastal, saline cotton field in Shandong province. Wang et al. (2010) found that the salinity threshold was $5.8 \mathrm{~g} \mathrm{~kg}^{-1}$ for cotton seedlings in the southern part of the Xinjiang Uygur Autonomous Region of China. Feng et al. (2011) reported threshold values of $5.03 \mathrm{~g} \mathrm{~kg}^{-1}$ at budding and $9.8 \mathrm{~g} \mathrm{~kg}^{-1}$ at flowering, with more suitable values of 2.77 and $5.84 \mathrm{~g} \mathrm{~kg}^{-1}$, respectively. Sun et al. (2009b) found that a salinity of $2.8 \mathrm{dS} \mathrm{m}^{-1}$ had no effect on cotton yield at bolling. These results indicate that the threshold of salt tolerance of cotton is $<6 \mathrm{~g} \mathrm{~kg}^{-1}$. Ramoliya and Pandey (2002) found that cotton was particularly sensitive to salinity during the seedling stage. High salinity can inhibit seed germination, emergence, growth. Highly saline soils can reduce nutrient uptake via ionic imbalances and competition, factors that lead to crop stunting, accompanied by lower quality and yield. Soil salinity must therefore be maintained at levels below the salt-tolerance threshold, particularly during the seedling stage.

Xinjiang is a typical arid and semi-arid region in China with scarce water resources. Increasing urban and industrial water demands is decreasing the availability of water for agriculture. Efficiency measures are required to address this problem. Drip irrigation with plastic mulch is one of the best methods to conserve water and increase field crop yields (Zhang et al., 2017; Zong et al., 2020; Qin et al., 2016; Yuan et al., 2019; Ospanbayev et al., 2017). The technique can regulate soil temperature, decrease soil salinity and enhance water-use efficiency (Cook et al., 2006; Li et al., 2017a; Filipović et al., 2016; Hu et al., 2018; Ning et al., 2015). Some studies have reported that cotton roots were mostly distributed in the upper $0.4 \mathrm{~m}$ of soil when drip irrigation was applied, and most roots were within the upper 0.2-0.3 m (Wei et al., 2002; Liu et al., 2011). Agricultural practices in the study region for increasing water content and decreasing salinity in the soil include winter and spring surface irrigation in early November and mid-March, with volumes of 3000 and $1500 \mathrm{~m}^{3} \mathrm{ha}^{-1}$, respectively. Irrigating at these times has advantages, but winter and spring irrigation can also raise the water table, increase deep water percolation and increase soil salinity. A new method has been developed to save water and ensure cotton emergence, and the most meet requirement water and salinity threshold during the seedling stage: dry seeding followed by drip irrigation with mulching during establishment, without winter and spring irrigation. This method can improve cotton yield, emergence rate, soil temperature and water conservation (Wang et al., 2006, 2012). Irrigation volume, however, is usually based on experience and can lead to the waste of freshwater and a decrease in emergence rate. These problems must therefore be solved.

Various empirical, analytical and numerical models have been developed (Philip, 1968; Warrick, 1974; Moncef et al., 2002; Kandelous et al., 2008; Dabral et al., 2012; Saxena et al., 2018; Nouri et al., 2019; Kilic, 2020; Karimi et al., 2020) and are widely used. Most of these studies, however, used either planar or axi-symmetrical twodimensional models (Nazari et al., 2020; Ghazouani et al., 2019; Shiri et al., 2020; Karandish and Šimůnek, 2018). Drip irrigation, though, presents a fully threedimensional flow problem, especially when two adjacent wetting patterns begin to overlap (Kandelous et al., 2011). The confluence of wetting fronts is common, and cotton is always planted in the overlap zone (the zone irrigated by both of a pair of adjacent drippers), hence knowledge of the distributions of water and salinity in the zone is very important for achieving high crop yields. The optimal irrigation volume must therefore be known to ensure efficient crop production and soil conservation. Numerical modeling using HYDRUS(2D/3D) software (Šimůnek et al., 2008), which is 
widely used to simulate the movement of water, heat and/or solutes in two or three dimensions in variably saturated porous media, was thus used in this study. (He et al., 2018; Grecco et al., 2019; Haghnazari et al., 2020). Cote et al. (2003) used HYDRUS2D software to analyze soil water and solute transport under subsurface drip irrigation. Karandish and Šimůnek (2018) studied the soil water movement under single point source drip irrigation. Zhang et al. (2018) studied the variation of horizontal diffusion radius and vertical infiltration depth of point source infiltration in clay loam soil under different emitter discharge, initial soil moisture content and volume mass, and the results showed that the horizontal and vertical diffusion of water in Latosol had an exponential relationship with drip irrigation time and positive correlation with flow rate. Zhao et al. (2018) established the dynamic model of soil water movement under the condition of point source drip irrigation and carried out numerical simulation according to the theory of unsaturated soil water movement. Fan et al. (2020) established the mathematical model of soil water movement and solute movement of buried point source and used the model to describe the distribution law of water and fertilizer movement of sandy loam and loam under the condition of subsurface drip irrigation. Shan et al. (2019) established the mathematical model of emitter flow rate of point source drip irrigation, analyzed the change process of each factor in the model with the emitter flow rate, and determined the main factors affecting the emitter flow rate design of point source drip irrigation based on the equivalent cylindrical wetted body model. To sum up, HYDRUS(2D/3D) software has been widely applied for different crops, such as almond, citrus, wine grapes, maize, eggplant, olive orchards and cotton (Phogat et al., 2020; Scognamiglio et al., 2019; Autovino et al., 2018) and also employed to desgin optimal irrigation strategies (Karandish and Šimůnek, 2019). Therefore, we decide to employed the HYDRUS(2D/3D) software to conduct research. The objectives of this study were to: (i) evaluate the accuracy and usefulness of the HYDRUS-3D model, (ii) determine optimal irrigation volumes under dry seeding and wetestablishment conditions using the model and (iii) provide a reference for designing suitable drip-irrigation schedules and system arrangements.

\section{Materials and methods}

\section{Experimental site}

Field experiments were conducted in 2009 and 2010 at the Management of Irrigation Station of BaZhou District in Korla County, China $\left(41^{\circ} 35^{\prime} \mathrm{N}, 86^{\circ} 10^{\prime} \mathrm{E}, 903 \mathrm{~m}\right.$ a.s.1.). The region is classified as a warm-temperate arid zone with a continental climate. The mean annual precipitation is approximately $58 \mathrm{~mm}$ (Liang et al., 2019), most of which falls between June and August. Mean annual evaporation from a free-water surface is 2273-2788 mm (Li et al., 2018). The long-term mean annual temperature is $10.5{ }^{\circ} \mathrm{C}$, with a maximum of $43.6{ }^{\circ} \mathrm{C}$ and a minimum of $-9.4{ }^{\circ} \mathrm{C}$ (Liang and Shi, 2021). Annual total sunshine is $3036 \mathrm{~h}$, and the annual frost-free period is $188 \mathrm{~d}$ (Chen et al., 2018). The emergence period of cotton generally lasts 10-15 days (from sowing to emergence), which requires low temperature of $12.1-13.2{ }^{\circ} \mathrm{C}$, effective accumulated temperature $\left(\geq 12{ }^{\circ} \mathrm{C}\right)$ of $57.3-1172{ }^{\circ} \mathrm{C}$ and active accumulated temperature $\left(\geq 10{ }^{\circ} \mathrm{C}\right)$ of $88.2-463.2{ }^{\circ} \mathrm{C}$. The seedling stage (from emergence to budding) generally lasts 30-40 days, requiring low temperature of $16.9-18.2{ }^{\circ} \mathrm{C}$, effective accumulated temperature $\left(\geq 19^{\circ} \mathrm{C}\right)$ of $32.2-$ $323.0{ }^{\circ} \mathrm{C}$ and active accumulated temperature $\left(\geq 10{ }^{\circ} \mathrm{C}\right)$ of $331.6-1411.6^{\circ} \mathrm{C}$. The bud 
stage (from budding to flowering) generally lasts 25-30 days, requiring low temperature of $12.8-18.1{ }^{\circ} \mathrm{C}$, effective accumulated temperature $\left(\geq 20^{\circ} \mathrm{C}\right)$ of $16.1-189^{\circ} \mathrm{C}$ and active accumulated temperature $\left(\geq 10^{\circ} \mathrm{C}\right)$ of $608.2-1061.6^{\circ} \mathrm{C}$. The flowering and Bolling stage (flowering to boll opening) generally lasts 50-70 days, requiring low temperature of 15.4-18.7 ${ }^{\circ} \mathrm{C}$, effective accumulated temperature $\left(\geq 20^{\circ} \mathrm{C}\right)$ of $34.6-324.5^{\circ} \mathrm{C}$ and active accumulated temperature $\left(\geq 10{ }^{\circ} \mathrm{C}\right)$ of $1114.6-1636.4{ }^{\circ} \mathrm{C}$ (Su et al., 2015).

The soil is sandy loam textured consisting $48 \%$ sand, $46 \%$ silt and $6 \%$ clay in the upper $0.6 \mathrm{~m}$ of the profile (Li et al., 2019). The average bulk density is $1.56 \mathrm{~g} \mathrm{~cm}^{-3}$ and the average field capacity is $0.255 \mathrm{~cm}^{3} \mathrm{~cm}^{-3}$ in the upper $0.6 \mathrm{~m}$ of the profile (Tan et al., 2018). The mineral content of the water used for irrigation is $0.8 \mathrm{~g} \mathrm{~L}^{-1}$.

\section{Experimental design}

Three treatment combinations were each applied to three $13.5 \times 10 \mathrm{~m}\left(135 \mathrm{~m}^{2}\right)$ plots, for a total of nine plots, in both 2009 and 2010. Each plot in 2009 comprised nine beds, each supplied with water by a single irrigation pipe, in which four rows of cotton seeds were planted $0.1 \mathrm{~m}$ apart, with $0.2 \mathrm{~m}$ between rows (Fig. 1) and covered with plastic mulch. The emitter spacing was $0.3 \mathrm{~m}$, and the discharge rate of the emitters was $3 \mathrm{~L} \mathrm{~h}^{-1}$. Each plot in 2010 also had nine beds, each with four rows of cotton that were covered with plastic mulch, but double (lateral) irrigation pipes were used. The emitter spacing was $0.3 \mathrm{~m}$, and the discharge rate of the emitters was $1.8 \mathrm{~L} \mathrm{~h}^{-1}$. The lateral pipes were $0.6 \mathrm{~m}$ apart, and two rows of cotton plants were planted $0.1 \mathrm{~m}$ apart and $0.1 \mathrm{~m}$ either side of each pipe, with a gap of $0.4 \mathrm{~m}$ in the center of the bed between each double row. The leaf area index (LAI) of cotton was determined by dividing the total actual leaf area by land area at the initial growth stage. The length and width of each leaf on 5 medium-level growing plants were recorded every 5 days and the products calculated as leaf area. Then actual leaf area was obtained by summing up all the leaf areas and converting the sum using a correction coefficient of 0.73 (Su et al., 2015). The average initial soil water contents in the plots were 0.21 and $0.20 \mathrm{~cm}^{3} \mathrm{~cm}^{-3}$ and the salinities were 7.3 and $8.3 \mathrm{~g} \mathrm{~kg}^{-1}$ in the 0-40 cm layer in 2009 and 2010, respectively. The salinity content was moderate (Hafsi et al., 2017). Soil samples were collected from four layers (0-10, 10-20, 20-30, and $30-40 \mathrm{~cm})$ at two locations $(0$ and $30 \mathrm{~cm}$ from an emitter, and in the center of the overlap region between two emitters, respectively) in each plot. The electrical conductivity $(E C)$ of soil-solution extracts (1:5 soil-water) was measured with a DDS307A conductivity meter (Shanghai Precision \& Scientific Instrument Inc., Shanghai, China). Salinity thresholds are usually expressed in $\mathrm{g} \mathrm{kg}^{-1}$ in China, so we determined the relationship between $\mathrm{g} \mathrm{kg}^{-1}$ and $\mathrm{dS} \mathrm{m} \mathrm{m}^{-1}$ as follows. A 1:5 soil-water mixture was shaken for $3 \mathrm{~min}$ and filtered. Sixty milliliters of filtrate was placed in a porcelain dish and heated in a water bath. The filtrate was then oven-dried in the dish for $4 \mathrm{~h}$, cooled for $30 \mathrm{~min}$, and weighed. The filtrate was dried for a further $2 \mathrm{~h}$ and reweighed, checking that the two measurements were equal. The solid residue was then mixed with $15 \%$ hydrogen peroxide, heated in a water bath, and the other operations were repeated. The relationship between $S$ and $E C_{1: 5}$ is given by Equation 1.

$$
S=4.088 E C_{1: 5} \quad R^{2}=0.997
$$

where $S$ is the salinity $\left(\mathrm{g} \mathrm{kg}^{-1}\right)$ and $E C_{1: 5}$ is the measured conductivity $\left(\mathrm{dS} \mathrm{m}^{-1}\right)$. 

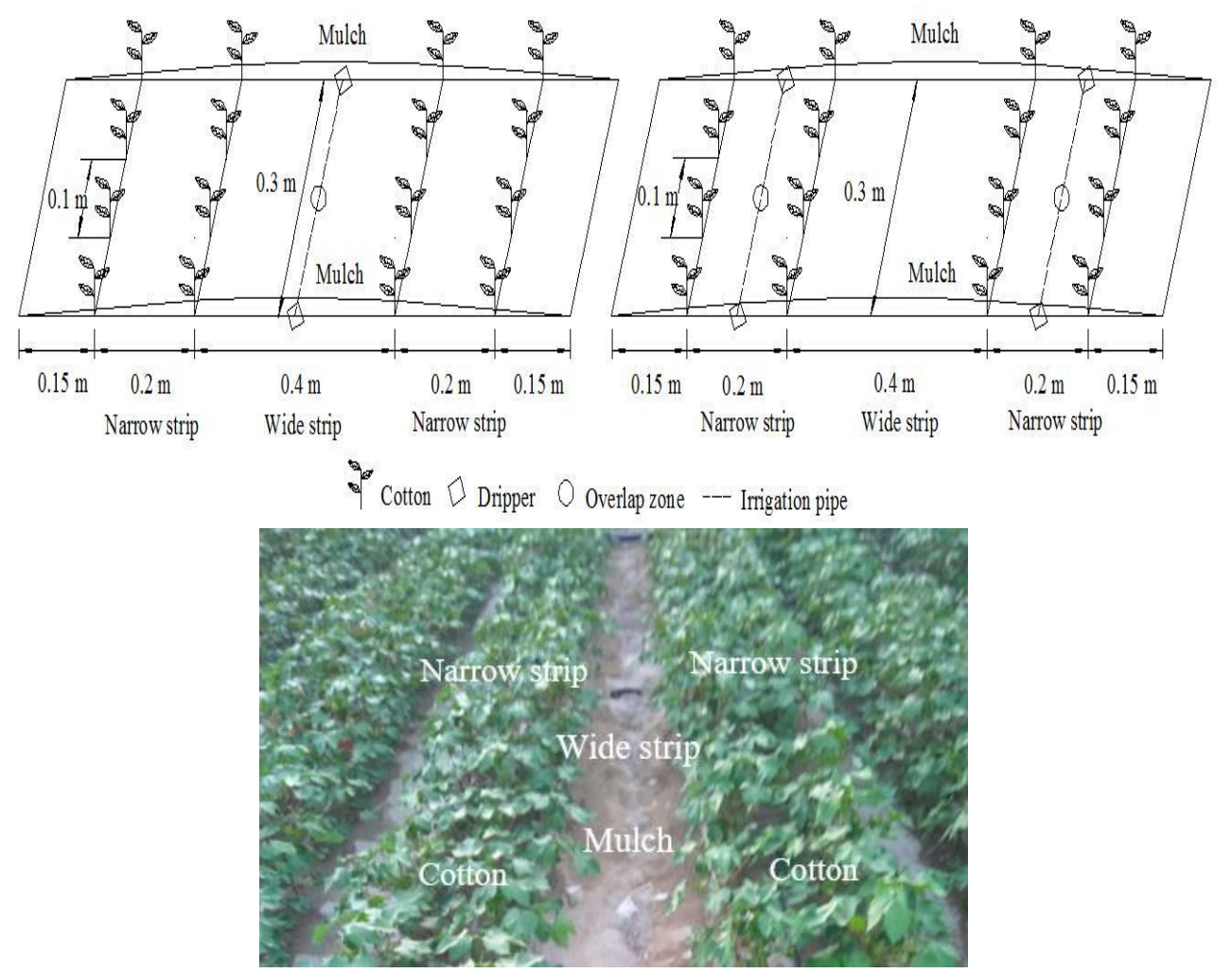

Figure 1. Schematic layout of the lateral pipes and cotton plants in each bed in the experimental plots

\section{Irrigation volume and fertilizer application}

Cotton seeds were planted on 26 April 2009 and on 28 April 2010. During the seedling stage, the irrigation volumes were $750 \mathrm{~m}^{3} \mathrm{ha}^{-1}$ on 30 April 2009 and $750 \mathrm{~m}^{3} \mathrm{ha}^{-1}$ on 2 May 2010. A compound fertilizer, consisting of urea $375 \mathrm{~kg} \mathrm{ha}^{-1}$, ammonium phosphate $300 \mathrm{~kg} \mathrm{ha}^{-1}$, potassium sulfate $300 \mathrm{~kg} \mathrm{ha}^{-1}$ and farm manure $215 \mathrm{~kg} \mathrm{ha}^{-1}$ was incorporated into the soil before planting. Fertilizer was also applied during cotton growth every two irrigation cycles (every $7 \mathrm{~d}$ ) at rates of urea $45 \mathrm{~kg} \mathrm{ha}^{-1}$ between budding and the start of bolling and urea $75 \mathrm{~kg} \mathrm{ha}^{-1}$ thereafter to the bolling peak. From the end of the seedling stage to the boll stage, spray insecticides were applied to cotton fields every 5-7 days to prevent cotton diseases and insect pests. Cotton was toppled at the end of July to control the growth of the main stem and ensure the formation of cotton yield.

\section{Numerical modeling}

\section{Water-flow simulation}

The equation governing flow for these conditions is given by the following modified form of Richards' equation (Eq. 2):

$$
\frac{\partial \theta}{\partial t}=\frac{\partial}{\partial x_{i}}\left[K\left(K_{i j}^{A} \frac{\partial h}{\partial x_{j}}+K_{i z}^{A}\right)\right]-S
$$


where $\theta$ is the volumetric water content $\left(\mathrm{cm}^{3} \mathrm{~cm}^{-3}\right), h$ is the pressure head $(\mathrm{cm}), t$ is time $(\min ), x_{i}(\mathrm{i}=1,2,3$ for a three-dimensional model) are spatial coordinates $(\mathrm{cm}), S$ is the sink term $\left(\mathrm{cm}^{3} \mathrm{~cm}^{-3} \mathrm{~min}^{-1}\right), K_{i j}^{A}$ and $K_{i z}^{A}$ are components of the dimensionless anisotropy hydraulic $K^{A}$ (dimensionless) and $K$ is the unsaturated hydraulic-conductivity function $\left(\mathrm{cm} \mathrm{min}^{-1}\right)$ given by conductivity tensor $(E q .3)$ :

$$
K(h, x, y, z)=K_{s}(x, y, z) K_{r}(h, x, y, z)
$$

where $K_{r}$ is the relative hydraulic conductivity (dimensionless) and $K_{\mathrm{s}}$ is the saturated hydraulic conductivity $\left(\mathrm{cm} \mathrm{min}{ }^{-1}\right)$.

The soil hydraulic properties were specified based on the van Genuchten model (Eqs. 4-6):

$$
\begin{gathered}
\theta(h)= \begin{cases}\theta_{r}+\frac{\left(\theta_{s}-\theta_{r}\right)}{\left(1+|\alpha h|^{n}\right)^{m}}, & h<0 \\
\theta_{s}, & h \geq 0\end{cases} \\
K(h)= \begin{cases}K_{s} S_{e}\left[1-\left(1-S_{e}^{1 / m}\right)^{m}\right]^{2}, & h<0 \\
K_{s}, & h \geq 0\end{cases} \\
S_{e}=\frac{\theta-\theta_{r}}{\theta_{s}-\theta_{r}}
\end{gathered}
$$

where $\theta_{s}$ is the saturated water content $\left(\mathrm{cm}^{3} \mathrm{~cm}^{-3}\right) ; \theta_{r}$ is the residual water content $\left(\mathrm{cm}^{3} \mathrm{~cm}^{-3}\right) ; \alpha, n$ and $l$ are shape parameters, with $m=1-1 / n$; and $S_{e}$ is the effective saturation.

\section{Salt-transport simulation}

Solute transport within the soil profile, which is controlled by both infiltration and diffusion, can be described by the advection-diffusion equation (Eq. 7):

$$
\theta \frac{\partial c}{\partial t}=\frac{\partial}{\partial x_{i}}\left(\theta D_{i j}^{w} \frac{\partial c}{\partial x_{j}}\right)-\frac{\partial q_{i} c}{\partial x_{i}}
$$

where $c$ is the solute concentration in the liquid $\left(\mathrm{g} \mathrm{L}^{-1}\right), D_{i j}^{w}$ is the effective dispersion coefficient tensor in the soil matrix $\left(\mathrm{cm}^{2} \mathrm{~min}^{-1}\right)$ and $q_{i}$ is a component of the fluid flux density.

\section{Root uptake}

The water-stress response-function model of Feddes et al. (1978) was used to account for water stress, and the threshold slope model of Khosla (1996) was used for salinity 
stress. Parameters of the water-and salinity-stress response functions were obtained from the literature (Feddes et al., 1978; Khosla, 1996; Rahneshan et al., 2018; Azad et al., 2018). A multiplicative model was used to account for the combined effects of water and salinity stress (Kumar et al., 2021). Cotton roots were sampled at a regular network of sampling points and measured using DT-SCAN (Chen et al., 2020). Root distributions of 57,38 and $5 \%$ at depths of 10, 20 and $30 \mathrm{~cm}$, respectively, were assumed based on the analysis the results. HYDRUS does not allow a temporally variable root zone, so a constant root distribution was used during the simulations (Han et al., 2015).

\section{Initial and boundary conditions}

Measured soil water contents and salinity were used as the initial conditions in the flow domain. Temporally variable boundary conditions under the mulch were applied for evaporation, transpiration, and precipitation were obtained from meteorological data. Daily precipitation and reference evapotranspiration $\left(E T_{o}\right)$ were recorded by a weather station within $30 \mathrm{~m}$ of the experimental field. The daily crop potential evapotranspiration $\left(E T_{p}\right)$ was calculated by Equation 8:

$$
E T_{p}=K_{c} \cdot E T_{o}
$$

where $K_{c}$ is the crop coefficient (0.45) at the seedling stage (Liu et al., 2013).

The $E T_{p}$ consists of potential transpiration $\left(T_{p}\right)$ and potential evaporation $\left(E_{p}\right)$, which are described by Equation 9 (Mahey et al., 1984; Campbell and Norman, 1989).

$$
\begin{gathered}
T_{p}=\left(1-e^{-k \cdot L A I}\right) E T_{p} \\
E_{p}=E T_{p}-T_{p}
\end{gathered}
$$

where $k$ is the radiation-extinction coefficient ( 0.58 for cotton; Srinet et al., 2019) and LAI is the leaf area index (0.05-0.20 at the seedling stage; Su et al., 2015).

The variable-flux boundary condition for irrigation was based on the length of daily irrigation. Water volumes coupled with irrigation timing were used to determine the input values for the variable-flux boundary condition used as the drip-irrigation source in the HYDRUS-3D simulation. The atmospheric boundary condition was used for bare soil. A constant-flux boundary condition was used along boundary elements representing the emitter during the application of water in simulations of the field experiment. The constant boundary fluxes represented the corresponding measured fluxes of the field experiments. The flux was calculated by dividing the discharge rate by the ponded-surface area of the boundary that represented an emitter in the HYDRUS model, because the HYDRUS model cannot describe changes in the ponded-surface area. We thus chose a constant value that was measured and calculated using the Bresler (1978) equation for 2009 and 2010, respectively. We used the equation in 2010 because the measured and calculated radii of the ponded-surface area in 2009 were 6.8 and $7.7 \mathrm{~cm}$, respectively. The emitter boundary became a zero-flux boundary after each irrigation. Zero-flux boundary conditions were also used for all three dimensions both during and after irrigation. A zero-flux condition was also used along the soil surface, because evaporation could be neglected due to the use of plastic mulch during irrigation. A free-drainage boundary condition was applied along the lower boundary. 
HYDRUS-3D uses the Galerkin finite-element method to solve the governing waterflow equation and the advection-diffusion equation. The transport domain was a set of rectangular parallel pipes $(170 \mathrm{~cm}$ long, $30 \mathrm{~cm}$ wide and $150 \mathrm{~cm}$ deep). Running the HYDRUS-3D model required specifying the hydraulic parameters $\theta_{s}, \theta_{r}, K_{s}, \alpha, n, l, D_{L}$ (Longitudinal Dispersivity) and $D_{T}$ (Transverse Dispersivity) (Table 1).

Table 1. Estimated soil hydraulic parameters in 2009 and 2010

\begin{tabular}{c|c|c|c|c|c|c|c|c}
\hline & $\begin{array}{c}\boldsymbol{\theta}_{\boldsymbol{r}} \\
\left(\mathbf{c m}^{\mathbf{3}} \mathbf{c m}^{-\mathbf{3}}\right)\end{array}$ & $\begin{array}{c}\boldsymbol{\theta}_{\boldsymbol{s}} \\
\left(\mathbf{c m}^{\mathbf{3}} \mathbf{c m}^{-\mathbf{3}}\right)\end{array}$ & $\begin{array}{c}\boldsymbol{\alpha} \\
\left(\mathbf{c m}^{-\mathbf{1}}\right)\end{array}$ & $\boldsymbol{n}$ & $\begin{array}{c}\boldsymbol{K}_{\boldsymbol{s}} \\
\left(\mathbf{c m ~ d}^{\mathbf{1}}\right)\end{array}$ & $\boldsymbol{l}$ & $\begin{array}{c}\boldsymbol{D}_{\boldsymbol{L}} \\
(\mathbf{c m})\end{array}$ & $\begin{array}{c}\boldsymbol{D}_{\boldsymbol{T}} \\
(\mathbf{c m})\end{array}$ \\
\hline 2009 & 0.0311 & 0.411 & 0.019 & 1.6 & 24.91 & 0.5 & 35.4 & 5.3 \\
2010 & 0.0391 & 0.420 & 0.016 & 1.8 & 30.24 & 0.5 & 30.0 & 6.7 \\
\hline
\end{tabular}

\section{Statistical analysis}

The performance of the model simulation was evaluated using two statistical indices. The mean absolute error (MAE) and the root mean square error (RMSE) quantified the differences between the observations and simulations and were calculated as Equations 10 and 11, respectively.

$$
\begin{gathered}
M A E=\frac{1}{N} \sum_{i=1}^{N}\left|P_{i}-O_{i}\right| \\
R M S E=\sqrt{\frac{1}{N} \sum_{i=1}^{N}\left(P_{i}-O_{i}\right)^{2}}
\end{gathered}
$$

where $P_{i}$ is a simulated value, $O_{i}$ is an observed value and $N$ is the total number of observed values.

\section{Results and discussion}

\section{Soil water content (SWC) and salinity}

SWC varied spatially, decreasing horizontally with distance from the drippers and vertically increasing with depth because most of the roots were distributed in the upper soil in both 2009 and 2010 (Figs. 2 and 3, respectively). Average SWCs at the end of the seedling stage were 0.22 and $0.18 \mathrm{~cm}^{3} \mathrm{~cm}^{-3}$ in 2009 and 2010, respectively. Average SWCs at the end of the seedling stage were 80 and $70 \%$ of the field capacity in 2009 and 2010, respectively. Chen et al. (2019) found that a reasonable SWC ranged from 60 to $80 \%$ of the field capacity at various stages, indicating that the irrigation volume was able to meet the water requirements of the crop. SWC was higher in 2009 than in 2010, perhaps salinity was higher in 2009 and exceeded the threshold for cotton at the seedling stage, thereby decreasing root uptake. Ramos et al. (2011), and Bazihizina et al. (2017) also found that higher salinity could decrease soil osmotic potential, reduce root uptake and thus increase SWC.

Soil salinity also varied over time in both 2009 and 2010 (Figs. 4 and 5, respectively), perhaps because evapotranspiration and root uptake increased. Salinity also increased horizontally with distance from the dripper and vertically with depth 
because the salt moved into deeper soil with the water. From irrigation event finished to the end of seedling stage, the soil salinity content increased by $55 \%, 28 \%, 22 \%, 9 \%$ and $57 \%, 29 \%, 22 \%, 13 \%$ for $10 \mathrm{~cm}, 20 \mathrm{~cm}, 30 \mathrm{~cm}, 40 \mathrm{~cm}$ in 2009 and 2010 , respectively. Li et al. (2018) also found that the upper soil TDS climbed up faster driven by their more pronounced transpiration through root water uptake. The reason is that cotton root mainly distribution in the upper soil layer and as evapotranspiration effects progressively prevailed, soil water started to transport towards the upper soil, it is result that the water was consumed and salinity left on the upper soil.

Average salinities at the end of the seedling stage were 6.3 and $5.8 \mathrm{~g} \mathrm{~kg}^{-1}$ in 2009 and 2010, respectively. Salinity was higher in 2009 than 2010, perhaps because the experimental layout differed between 2009 and 2010, including number of drip lines and emitter discharge. Chen et al. (2019) found that salt accumulation in the root zone was lower with a double than a single drip line under the same volume of irrigation. Emitter discharge could also account for the higher salinity in 2009 than 2010. A lower rate can limit surface ponding and improve the movement of water vertically but not horizontally, but a higher rate will have the opposite effect. Ghazouani (2019) found that increasing the rate of discharge increased the horizontal size of the wetted area and decreased the depth of wetted soil in the same soil type. Che et al. (2021) reported that a lower emitter discharge could leach salinity more than a higher rate. The optimal dripirrigation layout should thus have a double drip line and a low emitter discharge to ensure that the cotton does not suffer from salinity stress.

Water movement and solute transport can be complicated problems with drip irrigation due to three-dimensional infiltration (before the wetting fronts overlap) and to both two- and three-dimensional infiltration (after the wetting fronts overlap). The overlapped zone varied widely with the crop planted, so the distributions of water and salinity were also criteria for evaluating reasonable irrigation volumes. The distribution and change of water and salinity in the overlap zone was similar to under dripper. SWC and salinity were 0.21 and $0.18 \mathrm{~cm}^{3} \mathrm{~cm}^{-3}$ and 6.5 and $5.9 \mathrm{~g} \mathrm{~kg}^{-1}$ in 2009 and 2010 , respectively (not shown in figure). SWC was thus sufficient, and the salinity did not exceed the threshold and provided a suitable environment for cotton growth. The irrigation volume was also reasonable in 2010. The HYDRUS model is thus a feasible tool for designing optimal irrigation strategies.

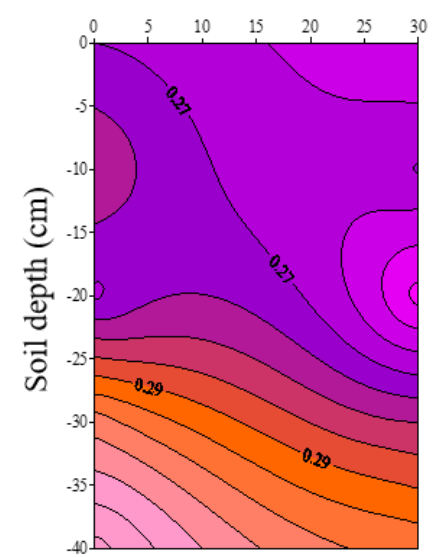

$3 \mathrm{~d}$ after irrigation

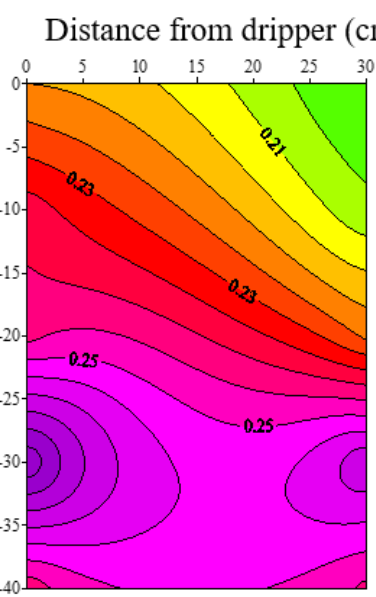

$24 \mathrm{~d}$ after irrigation

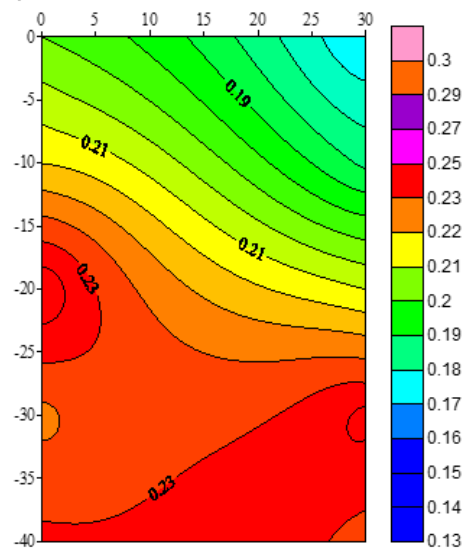

$44 \mathrm{~d}$ after irrigation

Figure 2. Variations of soil water content after single irrigation over time in 2009 


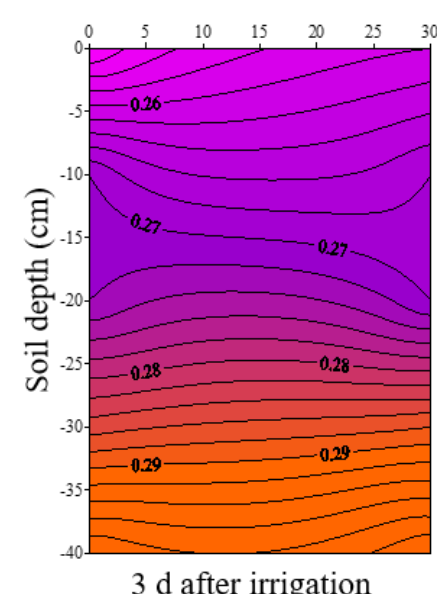

$3 \mathrm{~d}$ after irrigation

Distance from dripper $(\mathrm{cm})$

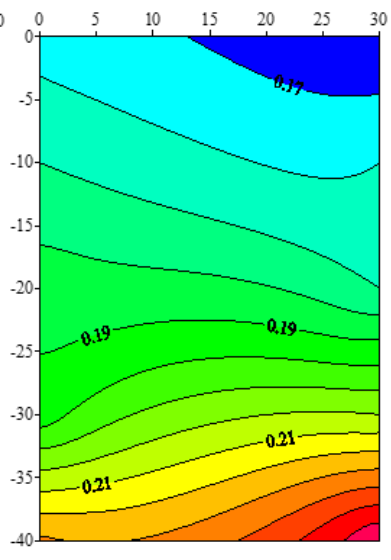

$24 \mathrm{~d}$ after irrigation

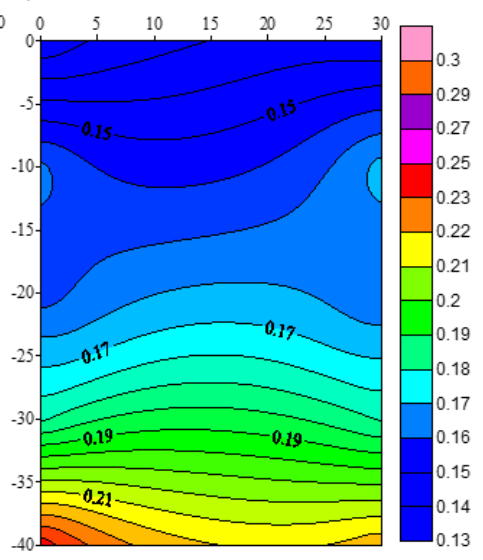

$44 \mathrm{~d}$ after irrigation

Figure 3. Variations of soil water content after single irrigation over time in 2010

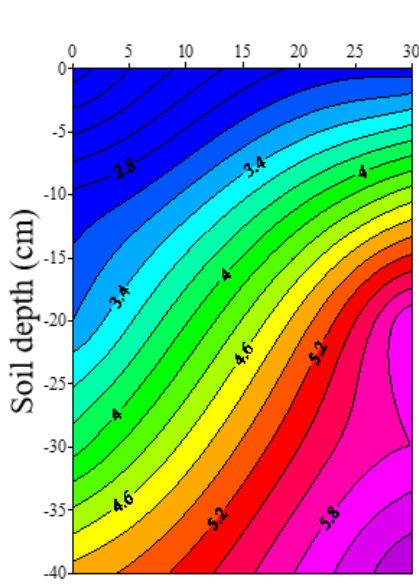

$3 \mathrm{~d}$ after irrigation

Distance from dripper $(\mathrm{cm})$

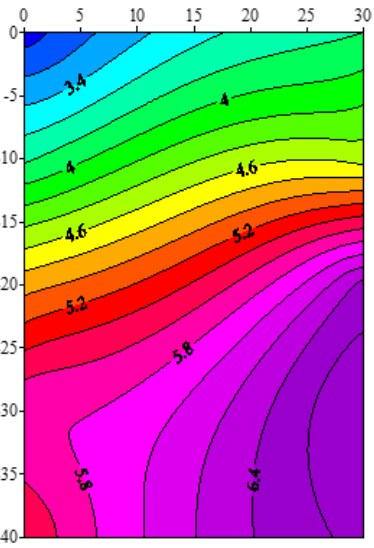

$24 \mathrm{~d}$ after irrigation

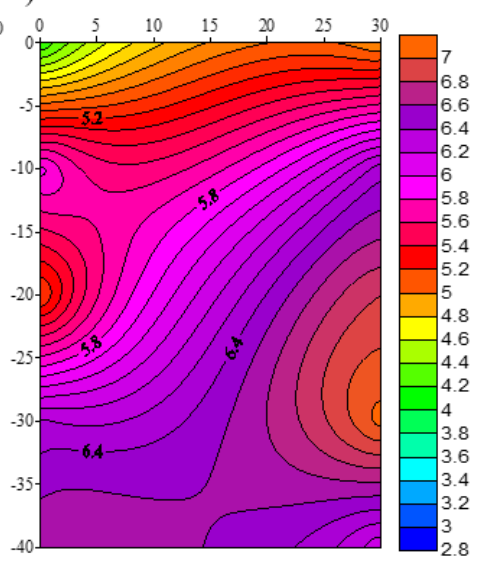

$44 \mathrm{~d}$ after irrigation

Figure 4. Variations of soil salinity after single irrigation over time in 2009

Distance from dripper $(\mathrm{cm})$

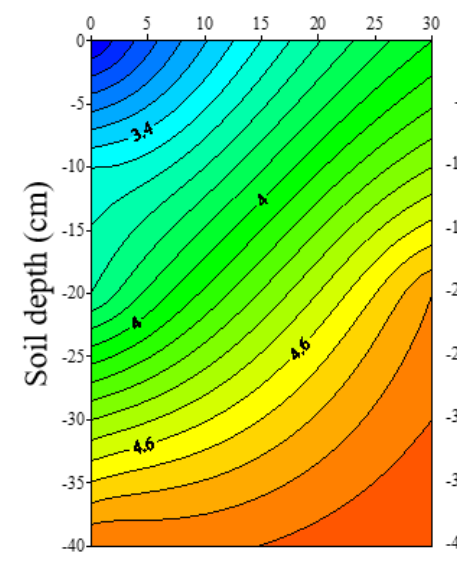

$3 \mathrm{~d}$ after irrigation

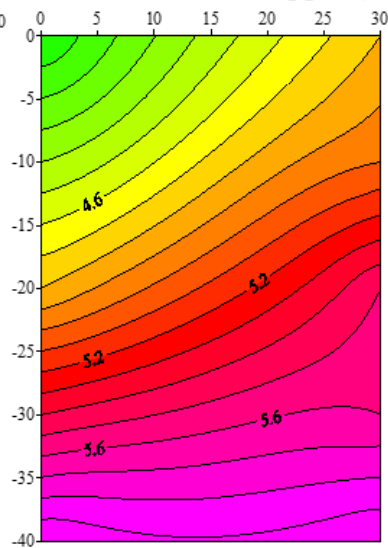

$24 \mathrm{~d}$ after irrigation

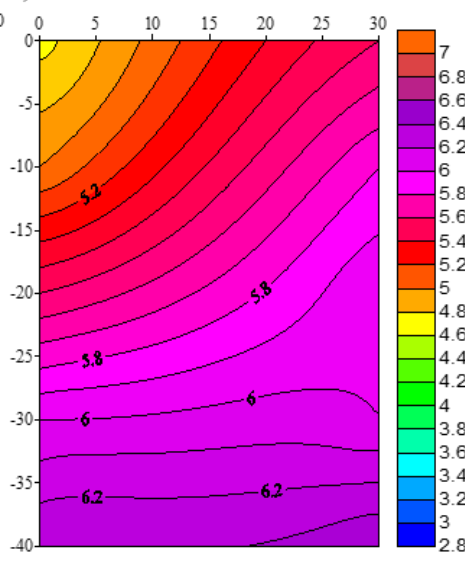

$44 \mathrm{~d}$ after irrigation

Figure 5. Variations of soil salinity after single irrigation over time in 2010 


\section{Model performance}

$R M S E$ is an index of the accuracy of model simulation. RMSE has the advantage of expressing the error in the same units as the variable, so it has often been used to compare simulated and measured parameters (Li et al., 2017; Xie et al., 2020; Chen et al., 2020). The lower the RMSE, the more accurate the simulation. MAE is another widely used index for evaluating the accuracy of model simulation (Chen et al., 2019). RMSE ranged from 0.008 to $0.022 \mathrm{~cm}^{3} \mathrm{~cm}^{-3}$ for SWC and from 0.29 to $0.5 \mathrm{~g} \mathrm{~kg}^{-1}$ for salinity, and MAE ranged from 0.005 to $0.011 \mathrm{~cm}^{3} \mathrm{~cm}^{-3}$ for SWC and from 0.24 to $0.6 \mathrm{~g} \mathrm{~kg}^{-1}$ for salinity (Tables 2-5). These values confirmed the strong relationship between measured and simulated SWC and salinity and indicated that the model could successfully simulate water movement and solute transport.

Table 2. Statistical comparison of measured and simulated soil-water contents at different positions in 2009

\begin{tabular}{c|c|c|c|c|c|c|c}
\hline \multirow{2}{*}{ Position } & \multirow{2}{*}{$\begin{array}{c}\text { Depth } \\
(\mathbf{c m})\end{array}$} & \multicolumn{2}{|c|}{ 3 d } & \multicolumn{2}{c|}{ 24 d } & \multicolumn{2}{c}{ 44 d } \\
\cline { 3 - 8 } & 10 & 0.280 & 0.275 & 0.238 & 0.226 & 0.215 & 0.210 \\
& 20 & 0.274 & 0.283 & 0.243 & 0.234 & 0.239 & 0.220 \\
Wide strip & 30 & 0.301 & 0.290 & 0.279 & 0.242 & 0.223 & 0.234 \\
& 40 & 0.312 & 0.294 & 0.211 & 0.251 & 0.231 & 0.245 \\
\hline \multirow{4}{*}{ Narrow } & 10 & 0.271 & 0.275 & 0.206 & 0.224 & 0.184 & 0.200 \\
strip & 20 & 0.275 & 0.286 & 0.224 & 0.232 & 0.210 & 0.216 \\
& 30 & 0.280 & 0.289 & 0.264 & 0.242 & 0.237 & 0.230 \\
& 40 & 0.298 & 0.293 & 0.244 & 0.251 & 0.228 & 0.240 \\
\hline \multirow{2}{*}{$\begin{array}{c}\text { Statistical } \\
\text { analysis }\end{array}$} & $R M S E\left(\mathrm{~cm}^{3} \mathrm{~cm}^{-3}\right)$ & \multicolumn{2}{|c|}{0.009} & \multicolumn{2}{c|}{0.019} & \multicolumn{2}{c}{0.012} \\
\hline
\end{tabular}

Table 3. Statistical comparison of measured and simulated salinities at different positions in 2009

\begin{tabular}{c|c|c|c|c|c|c|c}
\hline \multirow{2}{*}{ Position } & \multirow{2}{*}{$\begin{array}{c}\text { Depth } \\
(\mathbf{c m})\end{array}$} & \multicolumn{2}{|c|}{$\mathbf{3 ~ d}$} & \multicolumn{2}{c|}{ 24 d } & \multicolumn{2}{c}{ 44 d } \\
\cline { 2 - 8 } & & Observed & Simulated & Observed & Simulated & Observed & Simulated \\
\hline \multirow{4}{*}{ Wide strip } & 10 & 2.84 & 2.84 & 3.76 & 3.44 & 5.84 & 4.64 \\
& 20 & 3.20 & 3.64 & 4.92 & 3.80 & 5.08 & 4.80 \\
& 30 & 3.92 & 4.08 & 5.80 & 4.16 & 6.32 & 5.80 \\
& 40 & 4.88 & 4.48 & 5.40 & 4.80 & 6.60 & 6.20 \\
\hline \multirow{4}{*}{ Narrow } & 10 & 4.62 & 3.96 & 4.52 & 4.16 & 6.36 & 5.80 \\
strip & 20 & 6.00 & 5.04 & 6.48 & 5.20 & 6.80 & 6.50 \\
& 30 & 6.20 & 5.32 & 6.80 & 5.72 & 7.04 & 6.60 \\
& 40 & 6.40 & 5.60 & 6.64 & 6.00 & 6.40 & 6.80 \\
\hline \multirow{2}{*}{$\begin{array}{c}\text { Statistical } \\
\text { analysis }\end{array}$} & $R M S E\left(\mathrm{~cm}^{3} \mathrm{~cm}^{-3}\right)$ & \multicolumn{2}{|c|}{0.63} & \multicolumn{2}{c}{0.72} & \multicolumn{2}{c}{0.50} \\
\hline
\end{tabular}




$$
\text { - } 3690 \text { - }
$$

Table 4. Statistical comparison of measured and simulated soil-water contents at different positions in 2010

\begin{tabular}{c|c|c|c|c|c|c|c}
\hline \multirow{2}{*}{ Position } & \multirow{2}{*}{$\begin{array}{c}\text { Depth } \\
(\mathbf{c m})\end{array}$} & \multicolumn{2}{c|}{ 3 d } & \multicolumn{2}{c|}{ 24 d } & \multicolumn{2}{c}{ 44 d } \\
\cline { 2 - 8 } & & Observed & Simulated & Observed & Simulated & Observed & Simulated \\
\hline \multirow{4}{*}{ Wide strip } & 10 & 0.264 & 0.254 & 0.191 & 0.20 & 0.178 & 0.174 \\
& 20 & 0.272 & 0.260 & 0.200 & 0.210 & 0.174 & 0.187 \\
& 30 & 0.280 & 0.274 & 0.220 & 0.218 & 0.200 & 0.203 \\
& 40 & 0.302 & 0.280 & 0.240 & 0.230 & 0.223 & 0.219 \\
\hline \multirow{4}{*}{ Narrow } & 10 & 0.270 & 0.260 & 0.175 & 0.196 & 0.141 & 0.174 \\
strip & 20 & 0.275 & 0.268 & 0.180 & 0.206 & 0.151 & 0.187 \\
& 30 & 0.288 & 0.274 & 0.209 & 0.217 & 0.160 & 0.203 \\
& 40 & 0.300 & 0.288 & 0.219 & 0.228 & 0.233 & 0.210 \\
\hline \multirow{2}{*}{$\begin{array}{c}\text { Statistical } \\
\text { analysis }\end{array}$} & $R M S E\left(\mathrm{~cm}^{3} \mathrm{~cm}^{-3}\right)$ & \multicolumn{2}{|c|}{0.008} & \multicolumn{2}{c}{0.014} & \multicolumn{2}{c}{0.022} \\
\hline
\end{tabular}

Table 5. Statistical comparison of measured and simulated salinities at different positions in 2010

\begin{tabular}{c|c|c|c|c|c|c|c}
\hline \multirow{2}{*}{ Position } & \multirow{2}{*}{$\begin{array}{c}\text { Depth } \\
(\mathbf{c m})\end{array}$} & \multicolumn{2}{|c|}{ 3 d } & \multicolumn{2}{c|}{ 24 d } & \multicolumn{2}{c}{ 44 d } \\
\cline { 2 - 8 } & & Observed & Simulated & Observed & Simulated & Observed & Simulated \\
\hline \multirow{4}{*}{ Wide strip } & 10 & 4.44 & 4.32 & 4.8 & 4.41 & 4.5 & 5.00 \\
& 20 & 4.92 & 4.76 & 5.5 & 4.82 & 5.8 & 5.21 \\
& 30 & 5.03 & 5.10 & 5.70 & 5.24 & 6.00 & 5.64 \\
& 40 & 5.10 & 5.40 & 6.01 & 5.68 & 6.60 & 6.42 \\
\hline \multirow{4}{*}{ Narrow } & 10 & 3.53 & 3.68 & 4.20 & 4.00 & 5.21 & 4.81 \\
strip & 20 & 3.74 & 4.16 & 4.81 & 4.48 & 5.52 & 5.23 \\
& 30 & 4.42 & 4.67 & 5.42 & 4.96 & 6.00 & 5.68 \\
& 40 & 5.10 & 5.21 & 5.68 & 5.44 & 6.20 & 6.00 \\
\hline \multirow{2}{*}{$\begin{array}{c}\text { Statistical } \\
\text { analysis }\end{array}$} & $R M S E\left(\mathrm{~cm}^{3} \mathrm{~cm}^{-3}\right)$ & \multicolumn{2}{|c|}{0.29} & \multicolumn{2}{c}{0.44} & \multicolumn{2}{c}{0.36} \\
\hline
\end{tabular}

Accurate model simulation and the analysis of simulation errors are crucial for designing suitable irrigation regimes and for ensuring the applicability of the model (Shan et al., 2019). The analysis of our results identified several criteria for accurate simulation. The HYDRUS (2D/3D) model can not currently describe root growth, so a constant value must be chosen. The distribution of roots can control the dynamics of water and solutes, so these processes must be understood. Understanding root growth and distribution may play a vital role in simulating the dynamics of water and salinity throughout all growth stages. Future versions of the model must incorporate root development to minimize the simulation error. $L A I$ determines the accuracy of $T_{p}$, and the relationship between $T_{p}$ and $L A I$ is positive but the relationship between $T_{p}$ and $E_{p}$ is 
negative. $T_{p}$ is overestimated if $L A I$ is overestimated and $E_{p}$ is underestimated, and the simulation may lead to water stress in the soil. $T_{p}$ is underestimated if $L A I$ is underestimated and $E_{p}$ is overestimated, and the simulation may lead to salinity stress in the soil. Ning et al. (2021) found that overestimation of evaporation can lead to high salinity near the surface, which caused osmotic stress. LAI is small for cotton at the seedling stage, and choosing zero in the simulation produced good results ( $\mathrm{Li}$ et al., 2019). LAI in our study, however, was small at the initial seedling stage but increased by the end of the seedling stage, so we could not choose zero. Selecting zero may affect the accuracy of the simulation, so we selected values from 0.05 to 0.20 during the seedling stage and obtained satisfactory results. $L A I$ varies with growth stage and should be measured carefully and often at various stages using advanced equipment.

The accuracy of the simulation results was affected by the input parameters, so knowing the effects of the input parameters and using suitable methods of measurement or calculation are necessary to ensure that the results are sufficiently reliable and can play a vital role in the design of rational irrigation schedules. Chen et al. (2019) demonstrated that the inability of HYDRUS-2D to accurately predict all scenarios was not a limitation of the model but a limitation of our understanding of the parameters, such as actual ET, water uptake by plants and root growth and distribution.

\section{Effects of examined various factors on the optimal irrigation volume}

Optimal irrigation schedule and irrigation system determined by emitter discharge, emitter spacing, salinity content, soil textural and so on. Optimal irrigation volume not only can meet seedling emergency water content and salinity threshold, but also ensure crop demand water and not exceed salinity threshold during the seedling stage. In order to providing guide for local production, based on the local conditions we selected some factors, additional simulations were conducted with HYDRUS-3D, and evaluation irrigation uniformity (Christiansen uniformity coefficient, $C U$ ) and leaching rate $\left(L_{r}\right)$ using the information presented in Table 6.

Table 6. Parameters used in additional HYDRUS-3D simulations

\begin{tabular}{c|c|c|c|c|c|c}
\hline Case & Soil type & $\begin{array}{c}\text { Emitter spacing } \\
(\mathbf{c m})\end{array}$ & $\begin{array}{c}\text { Emitter } \\
\text { discharge }\left(\mathbf{L ~ h}^{-\mathbf{1}}\right)\end{array}$ & $\begin{array}{c}\text { Irrigation } \\
\text { volume }\end{array}$ & $\begin{array}{c}\text { Water content } \\
\left(\mathbf{c m}^{\mathbf{3}} \mathbf{c m}^{-\mathbf{3}} \mathbf{)}\right.\end{array}$ & $\begin{array}{c}\text { Salinity } \\
\left(\mathbf{g ~ k g}^{-\mathbf{1}}\right)\end{array}$ \\
\hline I & & 30 & $1.6,2.4,3.2$ & 10 & 0.15 & 8 \\
II & Sandy loam & $20,30,40$ & 1.6 & 10 & 0.15 & 8 \\
III & & 30 & 1.6 & 10 & 0.15 & $6,8,10$ \\
\hline
\end{tabular}

\section{Emitter discharge}

Emitter discharge play an important effect on water movement and salinity transport. Figure 6 showed that the water content and salinity distribution under the same irrigation volume. The water content is decrease with distance from the emitter and depth increase, but the salinity the opposite. Compared to among the various emitter discharge, emitter discharge bigger and water content higher in horizonal, but inverse for in vertical. As for salinity distribution, emitter discharge bigger and salinity content lower in horizonal, but inverse for in vertical. The $C U$ value were $0.757,0.728$ and 0.705 for emitter discharge $1.6 \mathrm{~L} \mathrm{~h}^{-1}, 2.4 \mathrm{~L} \mathrm{~h}^{-1}, 3.2 \mathrm{~L} \mathrm{~h}^{-1}$, respectively, we concluded that the $C U$ decrease with emitter discharge increase, and the relationship between $C U$ 
and emitter discharge $\left(E_{d}\right)$ has a followed power function $\left(C U=0.7948 E_{d}{ }^{-0.102}\right.$, $R^{2}=0.9983$ ). Wang et al. (2020) found that the $C U$ decrease with emitter discharge increase at the same irrigation volume and emitter spacing. Leaching rate results were shown in Table 7. According to Table 6 results, we found that smaller emitter discharge favor to pushing salinity to deeper soil, and the relationship between $L_{r}$ and emitter discharge $\left(E_{d}\right)$ has a followed linear function $\left(L_{r}=0.1842 E_{d}{ }^{-0.071}, R^{2}=0.9938\right)$. Wang et al. (2012), Liu et al. (2012), and Martynenko, et al. (2020) also showed that smaller emitter discharge is more favorable to soil movement and salinity leaching in vertical direction. Figure 7 showed that water and salinity distribution at the end of seedling stage determined on optimal irrigation volume was $720 \mathrm{~m}^{3} \mathrm{hm}^{-2}, 1050 \mathrm{~m}^{3} \mathrm{hm}^{-2}$ and $1275 \mathrm{~m}^{3} \mathrm{hm}^{-2}$ for emitter discharge $1.6 \mathrm{~L} \mathrm{~h}^{-1}, 2.4 \mathrm{~L} \mathrm{~h}^{-1}, 3.2 \mathrm{~L} \mathrm{~h}^{-1}$ by using HYDRUS-3D, respectively. Both irrigation volume $(V)$ and emitter discharge $\left(E_{d}\right)$ can describe linear function relationship $\left(V=346.88 E_{d}+182.5, R^{2}=0.988\right)$. Based on Figure 7 , it is shown that the soil water content and salinity can meet crop demand for growth. Above all, in order to ensure the crop health development, smaller emitter discharge should be priority to consideration.

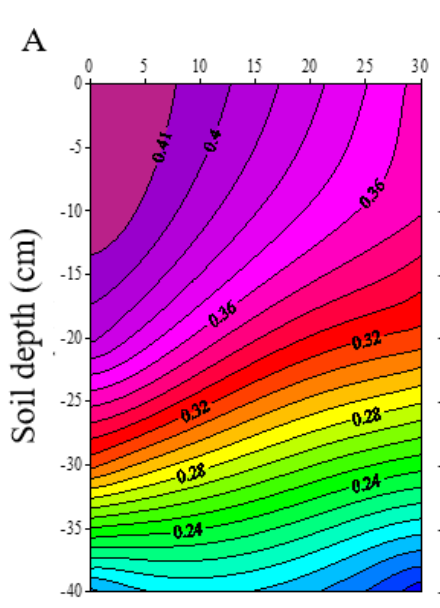

$1.6 \mathrm{~L} \mathrm{~h}^{-1}$

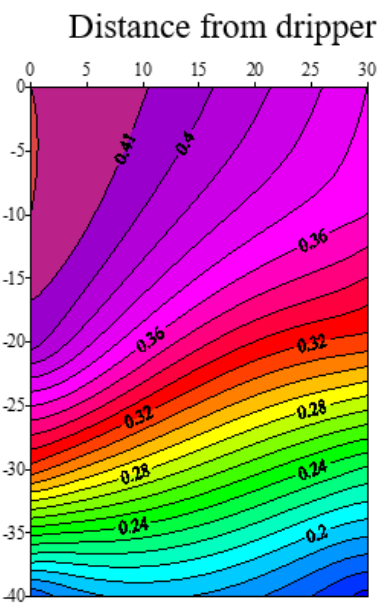

$2.4 \mathrm{~L} \mathrm{~h}^{-1}$

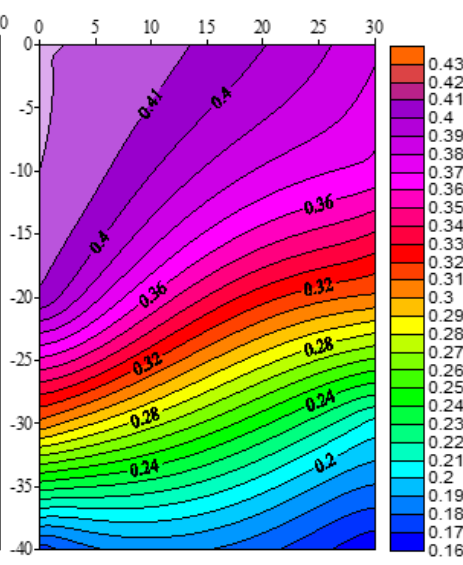

$3.2 \mathrm{~L} \mathrm{~h}^{-1}$

B

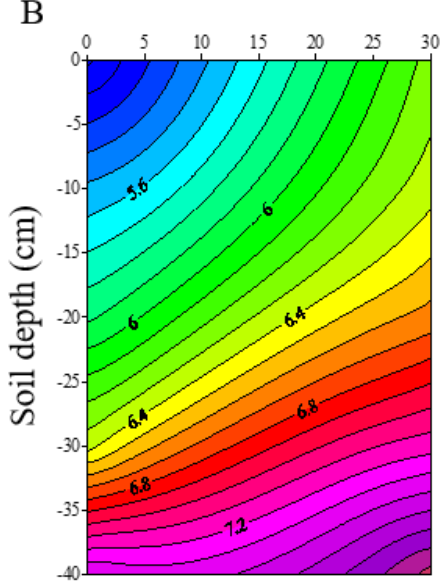

$1.6 \mathrm{~L} \mathrm{~h}^{-1}$

Distance from dripper $(\mathrm{cm})$

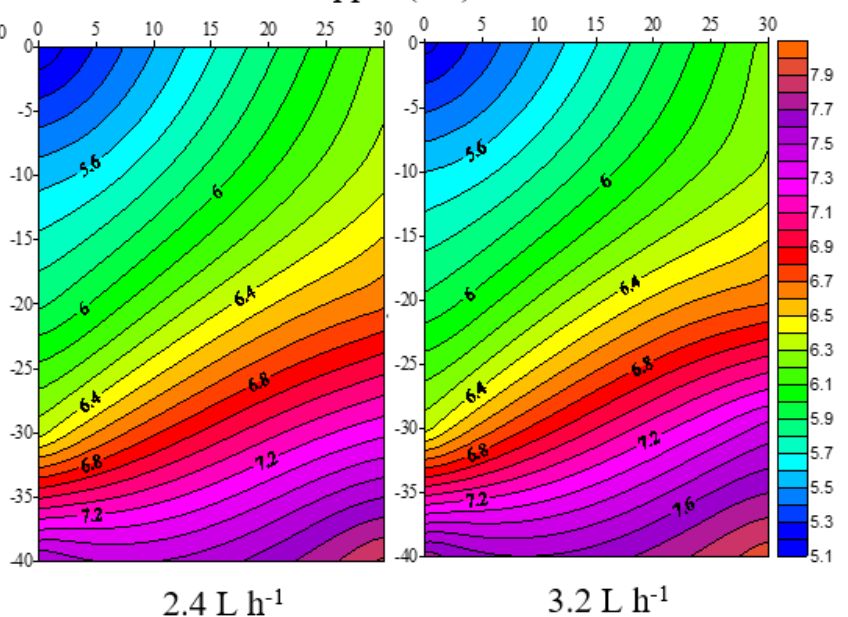

Figure 6. Distribution water content $(A)$ and salinity content $(B)$ at different emitter discharge after irrigation finished 
Table 7. The leaching rates at various emitter discharge after irrigation finished

\begin{tabular}{c|c|c|c}
\hline \multirow{2}{*}{ Depth (cm) } & \multicolumn{3}{|c}{ Emitter discharge $\left(\mathbf{L ~ h ~}^{\mathbf{- 1}}\right)$} \\
\cline { 2 - 4 } & $\mathbf{1 . 6}$ & $\mathbf{2 . 4}$ & $\mathbf{3 . 2}$ \\
\hline 10 & 0.292 & 0.289 & 0.280 \\
20 & 0.230 & 0.229 & 0.225 \\
30 & 0.169 & 0.163 & 0.156 \\
40 & 0.055 & 0.035 & 0.021 \\
Leaching rate in the soil profile & 0.184 & 0.176 & 0.170 \\
\hline
\end{tabular}

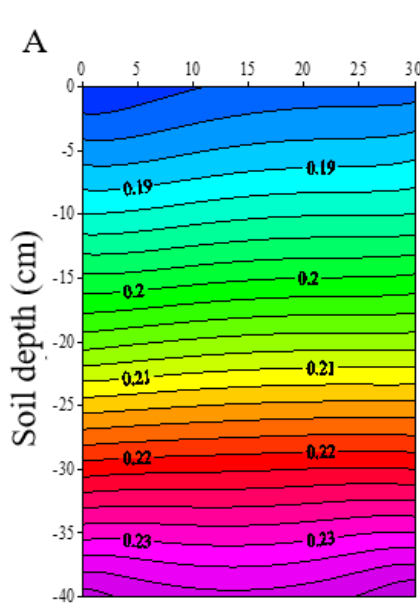

$1.6 \mathrm{~L} \mathrm{~h}^{-1}$

B

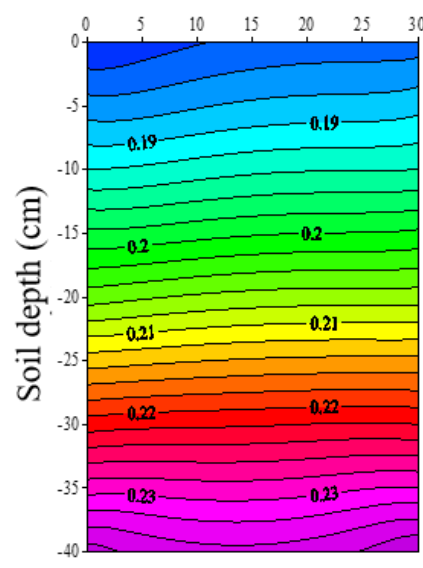

$1.6 \mathrm{~L} \mathrm{~h}^{-1}$

Distance from dripper $(\mathrm{cm})$

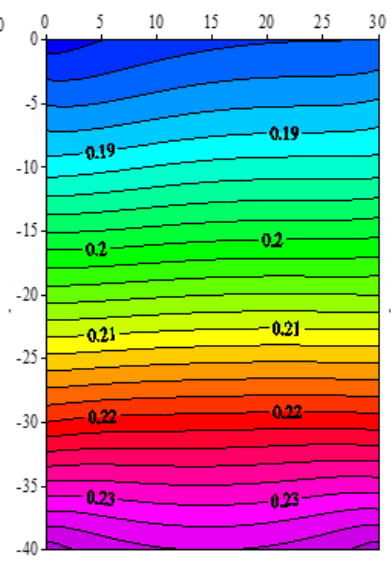

$2.4 \mathrm{~L} \mathrm{~h}^{-1}$

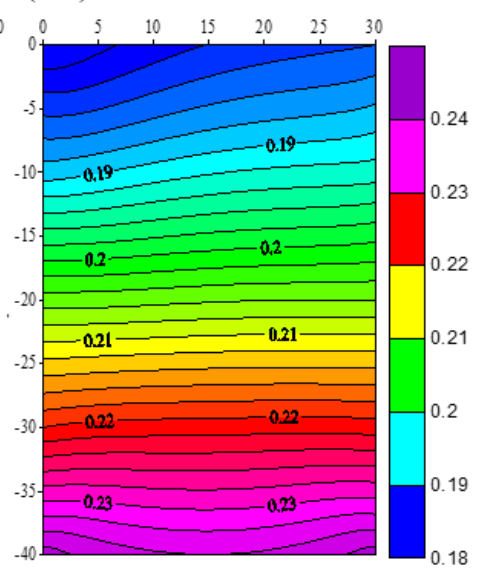

$3.2 \mathrm{~L} \mathrm{~h}^{-1}$

Distance from dripper $(\mathrm{cm})$

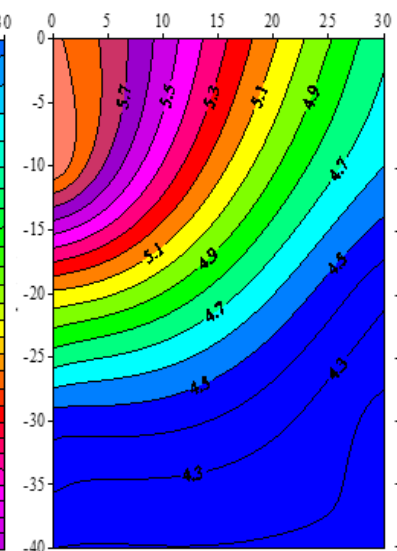

$2.4 \mathrm{~L} \mathrm{~h}^{-1}$

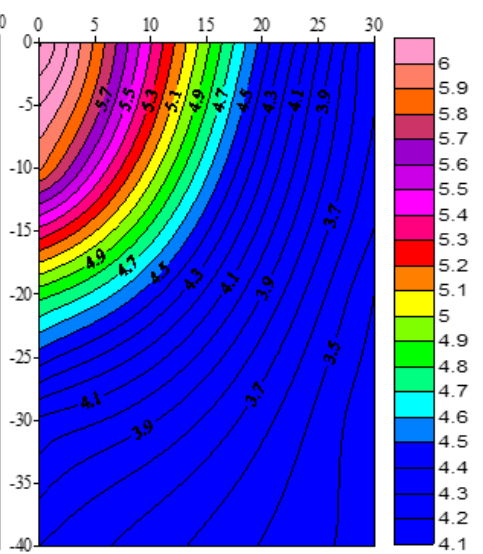

$3.2 \mathrm{~L} \mathrm{~h}^{-1}$

Figure 7. Distribution water content (A) and salinity content (B) at the end of seedling stage under optimal irrigation volume with various emitter discharge

\section{Emitter spacing}

Emitter spacing is an important part of drip irrigation system and also an important factor effecting on water movement and salinity transport. Figure $8 A$ and $B$ showed that the simulation results of water and salinity distribution under emitter spacing $20 \mathrm{~cm}$, 
$30 \mathrm{~cm}$ and $40 \mathrm{~cm}$ after irrigation is finished, respectively. According to Figure 8, it can be seen that the water content order is emitter spacing $20 \mathrm{~cm}>30 \mathrm{~cm}>40 \mathrm{~cm}$ in horizonal direction and in vertical direction. For the distribution of salinity content, the law is the opposite. The main reason is that the spacing is smaller, the wetting front confluence quickly, this will make the wet front advance fast, the wetting range is larger, the leaching effect is well. Li et al. (2017b) also showed that smaller emitter spacing more beneficial to salt leaching. The $C U$ value were $0.886,0.757$ and 0.679 for emitter spacing $20 \mathrm{~cm}, 30 \mathrm{~cm}, 40 \mathrm{~cm}$, respectively, we concluded that the relationship between $C U$ and emitter spacing $\left(E_{s}\right)$ has a followed power function relationship $\left(C U=2.8 E_{s}^{-0.384}, R^{2}=0.9998\right)$. Hu et al. (2018) showed that small emitter spacing more better improve $C U$. Leaching rate results shown in Table 8 , it is illustrated that the leaching rate decreases with depth increased, as well as emitter spacing increases. Both leaching rate $\left(L_{r}\right)$ and emitter spacing $\left(E_{s}\right)$ can be described power function $\left(L_{r}=1.921 E_{s}^{-0.692}, \mathrm{R}^{2}=0.9993\right)$. Figure 9 showed that optimal irrigation is $555 \mathrm{~m}^{3} \mathrm{hm}^{-2}$, $720 \mathrm{~m}^{3} \mathrm{hm}^{-2}, 840 \mathrm{~m}^{3} \mathrm{hm}^{-2}$ for emitter spacing $20 \mathrm{~cm}, 30 \mathrm{~cm}, 40 \mathrm{~cm}$, respectively. The relationship between irrigation volume $(V)$ and emitter spacing $\left(E_{\mathrm{s}}\right)$ has followed linear function $\left(V=14.25 E_{s}+277.5, R^{2}=0.9918\right)$. Take the $C U$ and $L_{r}$ into account, smaller spacing should be selected.

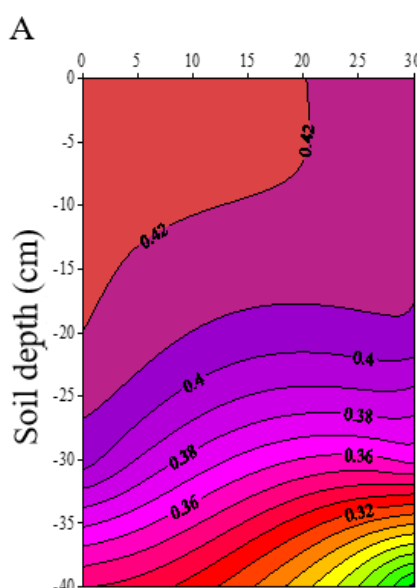

$20 \mathrm{~cm}$

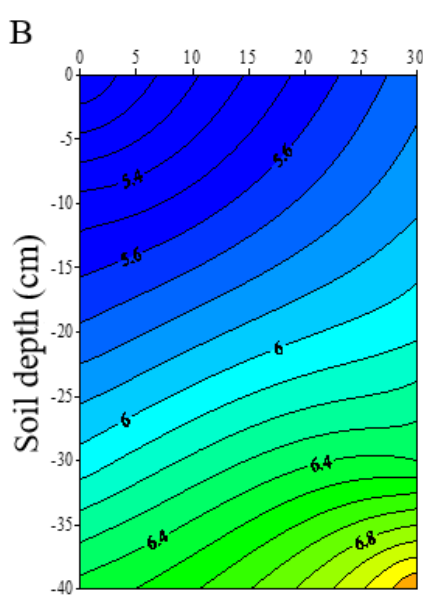

$20 \mathrm{~cm}$

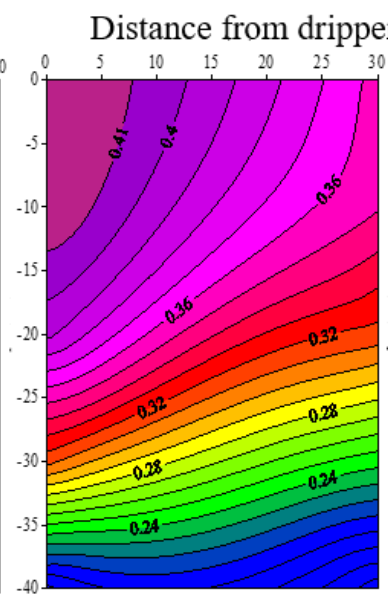

$30 \mathrm{~cm}$

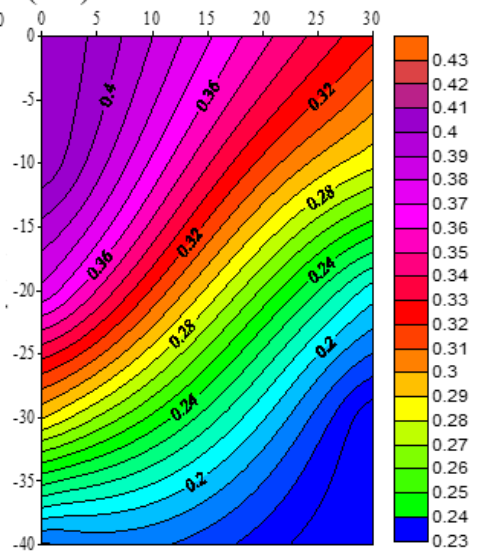

$40 \mathrm{~cm}$

Distance from dripper $(\mathrm{cm})$

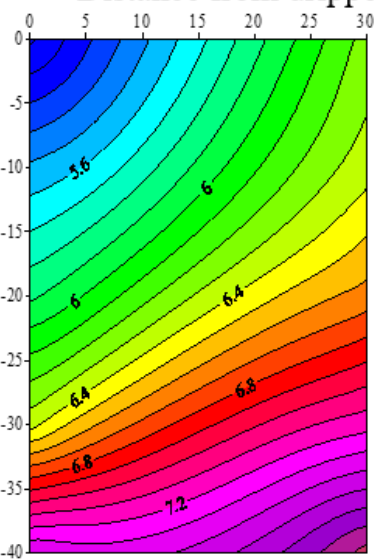

$30 \mathrm{~cm}$

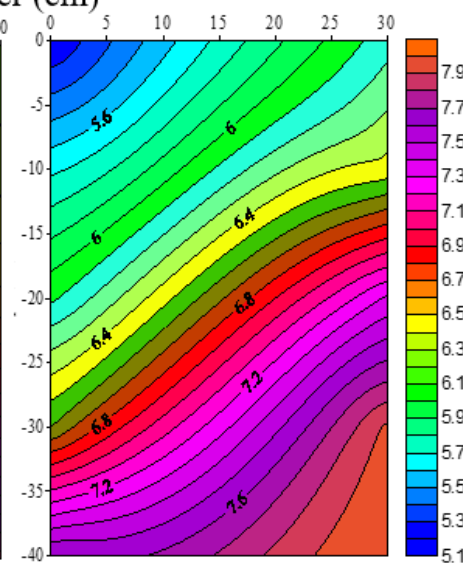

$40 \mathrm{~cm}$

Figure 8. Distribution water content (A) and salinity content (B) at different emitter spacing after irrigation finished 
Table 8. The leaching rates at various emitter spacing after irrigation finished

\begin{tabular}{c|c|c|c}
\hline \multirow{2}{*}{ Depth (cm) } & \multicolumn{3}{|c}{ Emitter spacing (cm) } \\
\cline { 2 - 4 } & $\mathbf{2 0}$ & $\mathbf{3 0}$ & $\mathbf{4 0}$ \\
\hline 10 & 0.321 & 0.292 & 0.280 \\
20 & 0.269 & 0.230 & 0.184 \\
30 & 0.229 & 0.169 & 0.115 \\
40 & 0.16 & 0.055 & 0.032 \\
Leaching rate in the soil profile & 0.241 & 0.184 & 0.149 \\
\hline
\end{tabular}

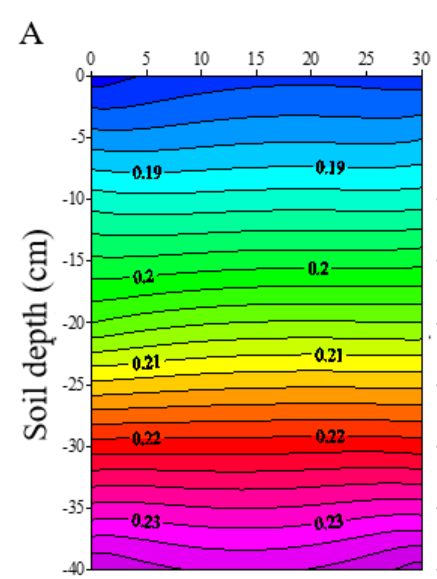

$20 \mathrm{~cm}$

B

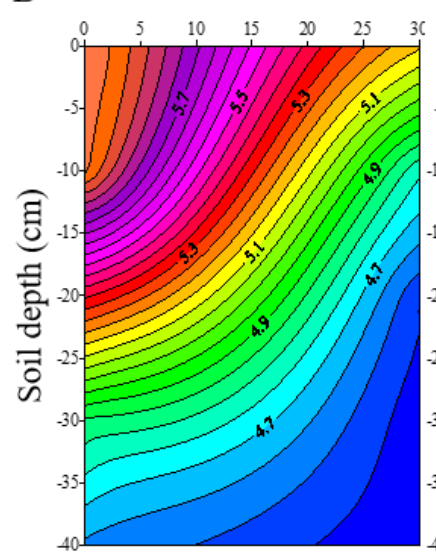

$20 \mathrm{~cm}$

Distance from dripper $(\mathrm{cm})$

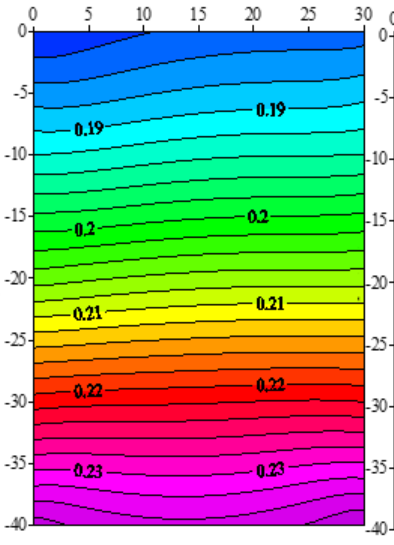

$30 \mathrm{~cm}$

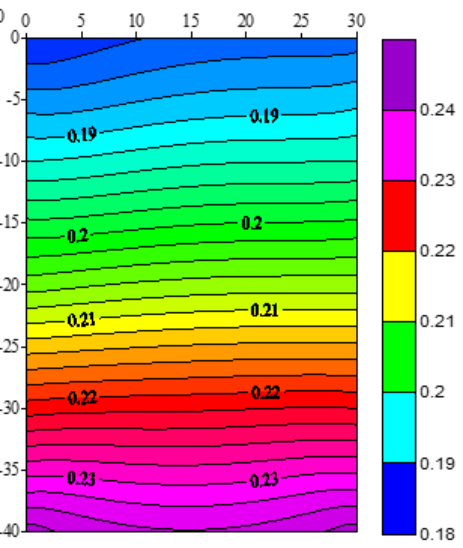

$40 \mathrm{~cm}$

Distance from dripper $(\mathrm{cm})$

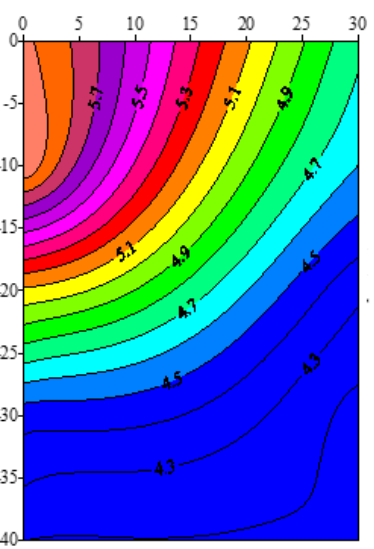

$30 \mathrm{~cm}$

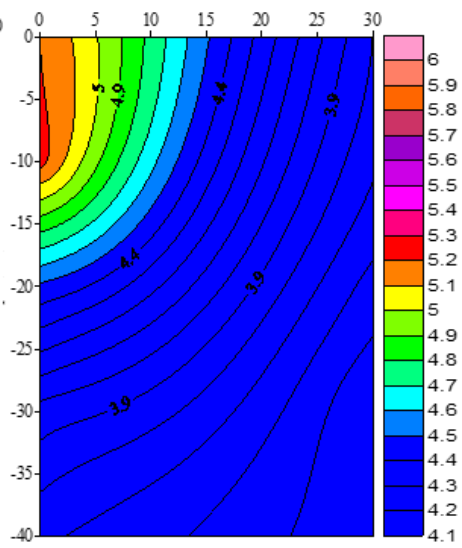

$40 \mathrm{~cm}$

Figure 9. Distribution water content (A) and salinity content (B) at the end of seedling stage under optimal irrigation volume with various emitter spacing

\section{Salinity content}

Salinity content can impact on the crop whole development stage and yield, and it is necessarily to consideration factor in design optimal irrigation schedule (Ning et al., 2021). The water content decreased with far away from emitter and depth increase (Fig. 10A), but as for salinity the law was opposite (Fig. 10B). The $C U$ value were almost the same 0.757 for salinity content $6 \mathrm{~g} \mathrm{~kg}^{-1}, 8 \mathrm{~g} \mathrm{~kg}^{-1}, 10 \mathrm{~g} \mathrm{~kg}^{-1}$, respectively. The results were similar to Long et al. (2019), thus we concluded that the salinity has no 
significance on $C U$. The leaching rate decreased with depth increase, but leaching rate increased as initial salinity content increased (Table 9). Both leaching rate $\left(L_{r}\right)$ and initial salinity content $(S)$ could be described power function $\left(L_{r}=0.0075 S^{1.50}\right.$, $\left.\mathrm{R}^{2}=0.970\right)$. Figure 11 showed that optimal irrigation was $450 \mathrm{~m}^{3} \mathrm{hm}^{-2}, 720 \mathrm{~m}^{3} \mathrm{hm}^{-2}$, $1050 \mathrm{~m}^{3} \mathrm{hm}^{-2}$ for emitter spacing $6 \mathrm{~g} \mathrm{~kg}^{-1}, 8 \mathrm{~g} \mathrm{~kg}^{-1}, 10 \mathrm{~g} \mathrm{~kg}^{-1}$, respectively. The relationship between irrigation volume $(V)$ and Salinity $(S)$ had followed linear function $\left(V=14.25 S+277.5, R^{2}=0.9967\right)$.

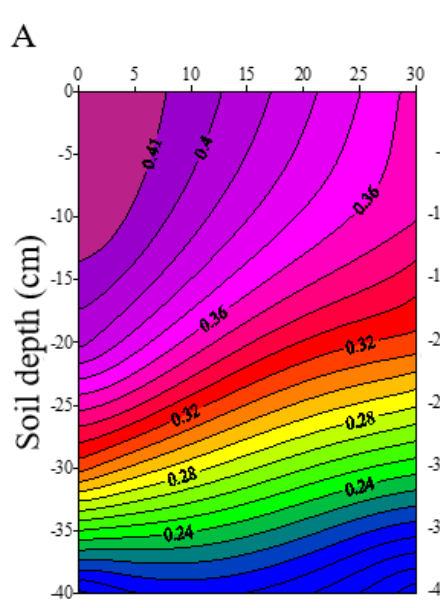

$6 \mathrm{~g} \mathrm{~kg}^{-1}$

B

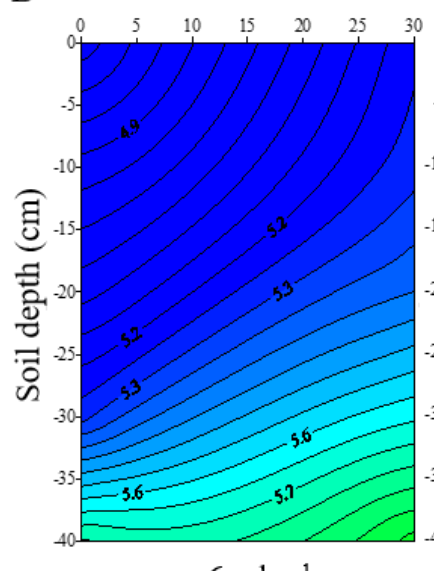

$6 \mathrm{~g} \mathrm{~kg}^{-1}$

Distance from dripper $(\mathrm{cm})$

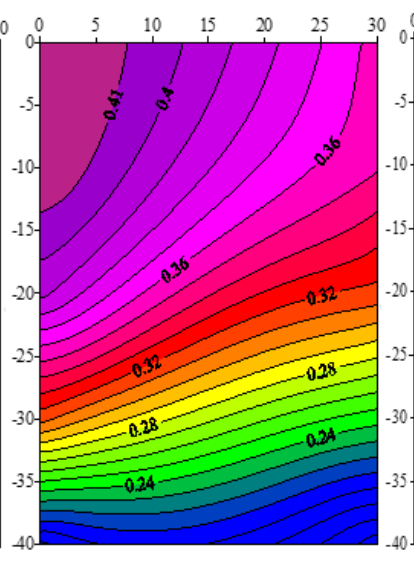

$8 \mathrm{~g} \mathrm{~kg}^{-1}$

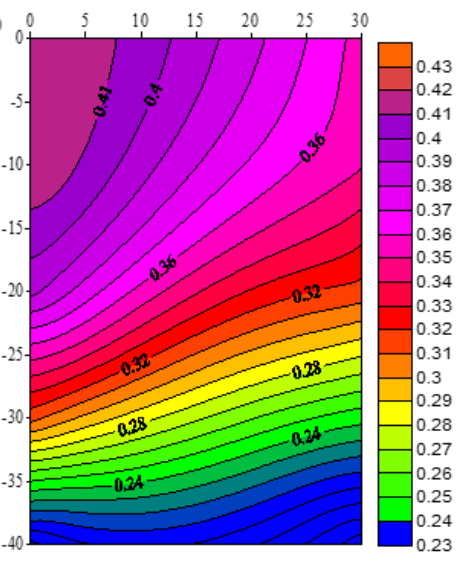

$10 \mathrm{~g} \mathrm{~kg}^{-1}$

Distance from dripper $(\mathrm{cm})$

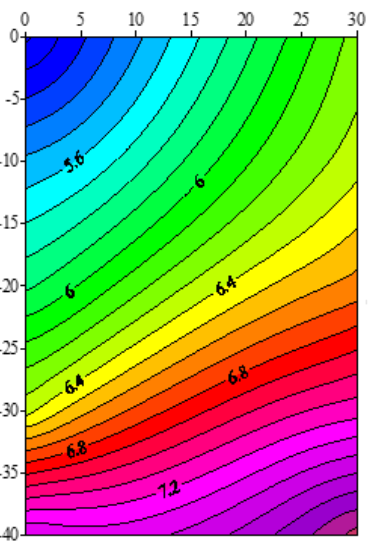

$8 \mathrm{~g} \mathrm{~kg}^{-1}$

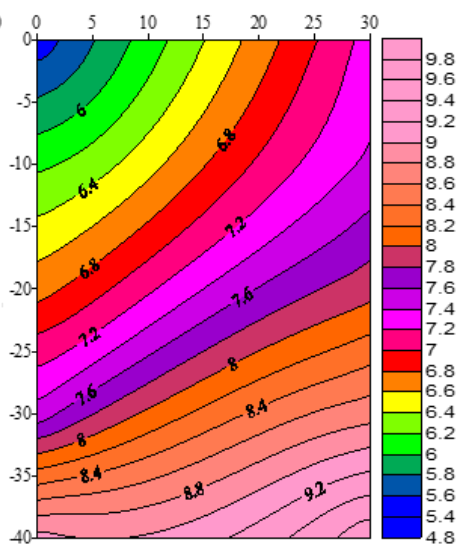

$10 \mathrm{~g} \mathrm{~kg}^{-1}$

Figure 10. Distribution water content $(A)$ and salinity content $(B)$ at different salinity content after irrigation finished

Table 9. The leaching rates at various initial salinity content after irrigation finished

\begin{tabular}{c|c|c|c}
\hline \multirow{2}{*}{ Depth $(\mathbf{c m})$} & \multicolumn{3}{|c}{ Salinity content $\left(\mathbf{g ~ k g}^{-\mathbf{1}}\right)$} \\
\cline { 2 - 4 } & $\mathbf{6}$ & $\mathbf{8}$ & $\mathbf{1 0}$ \\
\hline 10 & 0.17 & 0.292 & 0.362 \\
20 & 0.134 & 0.230 & 0.284 \\
30 & 0.098 & 0.169 & 0.207 \\
40 & 0.03 & 0.055 & 0.067 \\
Leaching rate in the soil profile & 0.064 & 0.184 & 0.227 \\
\hline
\end{tabular}



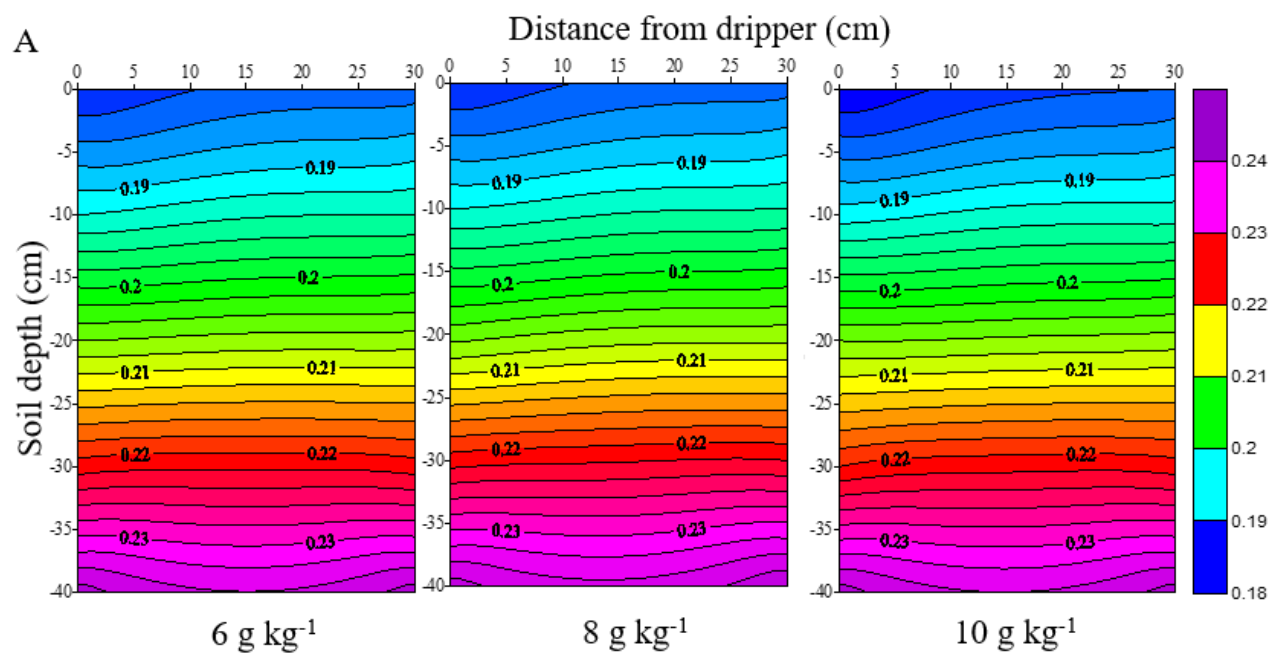

B

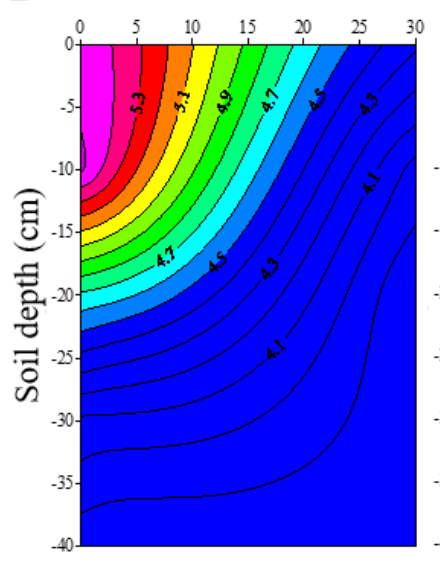

$6 \mathrm{~g} \mathrm{~kg}^{-1}$

Distance from dripper $(\mathrm{cm})$

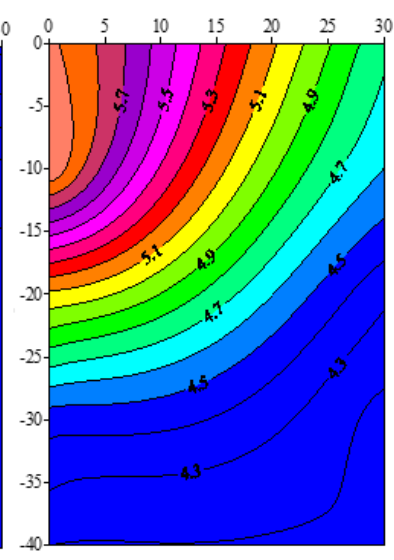

$8 \mathrm{~g} \mathrm{~kg}^{-1}$

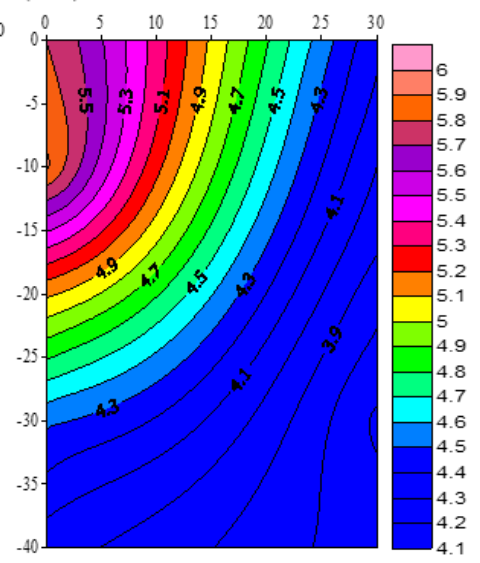

$10 \mathrm{~g} \mathrm{~kg}^{-1}$

Figure 11. Distribution water content (A) and salinity content $(B)$ at at the end of seedling stage under optimal irrigation volume with various salinity content

\section{Conclusions}

Improving water-use efficiency and constraining secondary soil salinity are effective measures for overcoming the limitation of agricultural development in arid and semi-arid regions. New technology, suitable system schemes and suitable irrigation regimes are essential for achieving these two goals. We found that dry seeding and planting after pregermination can significant save water compared to conventional winter and spring irrigation. Based on the salinity results, the suitable schedule is double line with one row, and emitter discharge should not choose large under soil salinity medium degree. HYDRUS-3D can become a useful tool for obtaining information about water movement and solute transport and for designing suitable irrigation regimes. Some problems need to be addressed before the technology can be better applied, such as accounting for variable soil texture and temperature and accommodating other crops. The HYDRUS model could also be improved in the future by incorporating root distribution and development. It is hoped that the research results can provided some value reference for designing robust irrigation system and irrigation schedule. Besides improving the function of the model, 
some key factors should be considered such as temperature. We will comprehensively consider water, salt, the temperature in the future study, not only in the seedling period but in the whole growth period. Reasonable irrigation volume is applied based on soil water stress threshold value, soil salinity stress threshold value, and temperature stress threshold of cotton at various growth stages.

Acknowledgements. This work was supported by the Major Special Science and Technology Project of Xinjiang Province (2020A01002-1).

\section{REFERENCES}

[1] Autovino, D., Rallo, G., Provenzano, G. (2018): Predicting soil and plant water status dynamic in olive orchards under different irrigation systems with Hydrus-2D: model performance and scenario analysis. - Agricultural Water Management 203: 225-235.

[2] Azad, N., Behmanesh, J., Rezaverdinejad, V., Abbasi, F., Navabian, M. (2018): Developing an optimization model in drip fertigation management to consider environmental issues and supply plant requirements. - Agricultural Water Management 208: 344-356.

[3] Bazihizina, N., Veneklaas, E. J., Barrett-Lennard, E. G., Colmer, T. D. (2017): Hydraulic redistribution: limitations for plants in saline soils. - Plant, Cell and Environment 40(10): 2437-2446.

[4] Bresler, E. (1978): Analysis of trickle irrigation with application to design problems. Irrigation science 1(1): 3-17.

[5] Campbell, G. S., Norman, J. M. (1989): The Description and Measurement of Plant Canopy Structure. - In: Russell, G. et al. (eds.) Plant Canopies: Their Growth, Form and Function (Society for Experimental Biology series). Cambridge University Press, Cambridge, pp. 1-19.

[6] Che, Z., Wang, J., Li, J. (2021): Effects of water quality, irrigation amount and nitrogen applied on soil salinity and cotton production under mulched drip irrigation in arid Northwest China. - Agricultural Water Management 247: 106738.

[7] Chen, W., Jin, M., Ferré, T. P., Liu, Y., Xian, Y., Shan, T., Ping, X. (2018): Spatial distribution of soil moisture, soil salinity, and root density beneath a cotton field under mulched drip irrigation with brackish and fresh water. - Field Crops Research 215: 207221.

[8] Chen, X., Qi, Z., Gui, D., Gu, Z., Ma, L., Zeng, F., Li, L. (2019): Simulating impacts of climate change on cotton yield and water requirement using RZWQM2. - Agricultural Water Management 222: 231-241.

[9] Chen, X., Qi, Z., Gui, D., Sima, M. W., Zeng, F., Li, L., Li, X., Gu, Z. (2020): Evaluation of a new irrigation decision support system in improving cotton yield and water productivity in an arid climate. - Agricultural Water Management 234: 106139.

[10] Cook, H. F., Valdes, G. S., Lee, H. C. (2006): Mulch effects on rainfall interception, soil physical characteristics and temperature under Zea mays L. - Soil and Tillage Research 91(1-2): 227-235.

[11] Cote, C. M., Bristow, K. L., Charlesworth, P. B., Cook, F. J., Thorburn, P. J. (2003): Analysis of soil wetting and solute transport in subsurface trickle irrigation. - Irrigation Science 22(3-4): 143-156.

[12] Dabral, P. P., Pandey, P. K., Ashish, P., Singh, K. P., Sanjoy, S. M. (2012): Modeling of wetting pattern under trickle source in sandy soil of Nirjuli Pradesh (India). - Irrigation Science 30: 287-292. 
[13] Dong, H. Z., Xin, C. S., Li, W. J. (2009): Characteristics of salinity and fertility in coastal saline cotton fields in Shandong and their effects on cotton emergence. - Cotton Science 21(4): 290-295 (in Chinese with an English abstract).

[14] Fan, Y., Shao, X., Gong, J., Wang, Y. (2020): An empirical model for estimating soil wetting pattern dimensions during film hole irrigation. - Archives of Agronomy and Soil Science 66(13): 1765-1779.

[15] Feddes, R. A., Kowalik, P. J., Zaradny, H. (1978): Simulation of Field Water Use and Crop Yield. - In: Penning de Vries, F. W. T., van Laar, H. H. (eds.) Simulation of Plant Growth and Crop Production. Simulation Monographs. Pudoc, Wageningen, pp. 188-189.

[16] Feng, D., Zhang, J. P., Sun, J. S., Li, K. J., Liu, Z. K., Ma, J. Y. (2011): Research on antisalinity indexes and eigenvalue of cotton under alternative irrigation with fresh and saline water. - China Rural Water and Hydropower 7: 1-4 (in Chinese with an English abstract).

[17] Filipović, V., Romić, D., Romić, M., Borošić, J., Filipović, L., Mallmann, F. J. K., Robinson, D. A. (2016): Plastic mulch and nitrogen fertigation in growing vegetables modify soil temperature, water and nitrate dynamics: experimental results and a modeling study. - Agricultural Water Management 176: 100-110.

[18] Ghazouani, H., Rallo, G., Mguidiche, A., Latrech, B., Douh, B., Boujelben, A., Provenzano, G. (2019): Assessing Hydrus-2D model to investigate the effects of different on-farm irrigation strategies on potato crop under subsurface drip irrigation. - Water 11(3): 540.

[19] Grecco, K. L., de Miranda, J. H., Silveira, L. K., van Genuchten, M. T. (2019): HYDRUS-2D simulations of water and potassium movement in drip irrigated tropical soil container cultivated with sugarcane. - Agricultural Water Management 221: 334-347.

[20] Hafsi, C., Falleh, H., Saada, M., Ksouri, R., Abdelly, C. (2017): Potassium deficiency alters growth, photosynthetic performance, secondary metabolites content, and related antioxidant capacity in Sulla carnosa grown under moderate salinity. - Plant Physiology and Biochemistry 118: 609-617.

[21] Haghnazari, F., Karandish, F., Darzi-Naftchali, A., Šimůnek, J. (2020): Dynamic assessment of the impacts of global warming on nitrate losses from a subsurface-drained rainfed-canola field. - Agricultural Water Management 242: 106420.

[22] Han, M., Zhao, C., Feng, G., Yan, Y., Sheng, Y. (2015): Evaluating the effects of mulch and irrigation amount on soil water distribution and root zone water balance using HYDRUS-2D. - Water 7(6): 2622-2640.

[23] He, Q., Li, S., Kang, S., Yang, H., Qin, S. (2018): Simulation of water balance in a maize field under film-mulching drip irrigation. - Agricultural Water Management 210: 252260.

[24] $\mathrm{Hu}$, J., Wu, J., Qu, X. (2018): Decomposition characteristics of organic materials and their effects on labile and recalcitrant organic carbon fractions in a semi-arid soil under plastic mulch and drip irrigation. - Journal of Arid Land 10(1): 115-128.

[25] Jia, Y. Z., Zhu, X. Y., Tang, Y. D., Cai, Y. L., Lin, T. B., Luo, X. B., Yang, Z. G., Han, H. H. (1987): Research on the targets tolerant towards salt in cotton emergence and seedling stage. - Acta Agricultural University Henan 21(1): 30-41 (in Chinese with an English abstract).

[26] Kandelous, M., Liaghat, A., Abbasi, F. (2008): Estimation of soil moisture pattern in subsurface drip irrigation using dimensional analysis method. - The Journal of Agricultural Science 39(2): 371-378.

[27] Kandelous, M. M., Šimůnek, J., van Genuchten, M. T., Malek, K. (2011): Soil water content distributions between two emitters of a subsurface drip irrigation system. - Soil Science Society of America Journal 75(2): 488-497.

[28] Karandish, F., Šimůnek, J. (2018): An application of the water footprint assessment to optimize production of crops irrigated with saline water: a scenario assessment with HYDRUS. - Agricultural Water Management 208: 67-82. 
[29] Karandish, F., Šimůnek, J. (2019): A comparison of the HYDRUS (2D/3D) and SALTMED models to investigate the influence of various water-saving irrigation strategies on the maize water footprint. - Agricultural Water Management 213: 809-820.

[30] Karimi, B., Mohammadi, P., Sanikhani, H., Salih, S. Q., Yaseen, Z. M. (2020): Modeling wetted areas of moisture bulb for drip irrigation systems: an enhanced empirical model and artificial neural network. - Computers and Electronics in Agriculture 178: 105767.

[31] Khosla, B. K. (1996): Agricultural salinity assessment and management. - Journal of the Indian Society of Soil Science 44(2): 360-360.

[32] Kilic, M. (2020): A new analytical method for estimating the 3D volumetric wetting pattern under drip irrigation system. - Agricultural Water Management 228: 105898.

[33] Kumar, S., Sonkar, I., Gupta, V., Hari Prasad, K. S., Ojha, C. S. P. (2021): Effect of salinity on moisture flow and root water uptake in sandy loam soil. - Journal of Hazardous, Toxic, and Radioactive Waste 25(3): 04021016.

[34] Li, X., Šimůnek, J., Shi, H., Yan, J., Peng, Z., Gong, X. (2017a): Spatial distribution of soil water, soil temperature, and plant roots in a drip-irrigated intercropping field with plastic mulch. - European Journal of Agronomy 83: 47-56.

[35] Li, Y., Šimůnek, J., Wang, S., Yuan, J., Zhang, W. (2017b): Modeling of soil water regime and water balance in a transplanted rice field experiment with reduced irrigation. - Water 9(4): 241-248.

[36] Li, X., Jin, M., Zhou, N., Jiang, S., Hu, Y. (2018): Inter-dripper variation of soil water and salt in a mulched drip irrigated cotton field: advantages of 3-D modelling. - Soil and Tillage Research 184: 186-194.

[37] Li, M., Du, Y., Zhang, F., Bai, Y., Fan, J., Zhang, J., Chen, S. (2019): Simulation of cotton growth and soil water content under film-mulched drip irrigation using modified CSM-CROPGRO-cotton model. - Agricultural Water Management 218: 124-138.

[38] Liang, J., Shi, W. (2021): Cotton/halophytes intercropping decreases salt accumulation and improves soil physicochemical properties and crop productivity in saline-alkali soils under mulched drip irrigation: a three-year field experiment. - Field Crops Research 262: 108027.

[39] Liang, J., Shi, W., He, Z., Pang, L., Zhang, Y. (2019): Effects of poly- $\gamma$-glutamic acid on water use efficiency, cotton yield, and fiber quality in the sandy soil of southern Xinjiang, China. - Agricultural Water Management 218: 48-59.

[40] Liu, L., Dong, X. G., Yang, X. X., Yang, P. N. (2011): Effect of soil water and salt dynamics on temporal and spatial distribution characteristics of cotton root under mulch drip Irrigation. - Water Saving Irrigation 1: 1-5 (in Chinese with an English abstract).

[41] Liu, M. X., Yang, J. S., Li, X. M., Mei, Y. U., Wang, J. (2012): Effects of irrigation water quality and drip tape arrangement on soil salinity, soil moisture distribution, and cotton yield (Gossypium hirsutum L.) under mulched drip irrigation in Xinjiang, China. Journal of Integrative Agriculture 11(3): 502-511.

[42] Liu, M. X., Yang, J. S., Li, X. M., Yu, M., Wang, J. (2013): Numerical simulation of soil water dynamics in a drip irrigated cotton field under plastic mulch. - Pedosphere 2013 23(5): 620-635.

[43] Long, L., Yang, W. W., Liao, P., Guo, Y. W., Kumar, A., Gao, W. (2019): Transcriptome analysis reveals differentially expressed ERF transcription factors associated with salt response in cotton. - Plant Science 281: 72-81.

[44] Martynenko, A., Kudra, T. (2020): Electrohydrodynamic dryer: effect of emitters' density and gap between discharge and collecting electrodes. - Drying Technology 38(1-2): 158167.

[45] Moncef, H., Hedi, D., Jelloul, B., Mohamed, M. (2002): Approach for predicting the wetting front depth beneath a surface point source: theory and numerical aspect. Irrigation and Drainage 51: 347-360. 
[46] Nazari, E., Besharat, S., Zeinalzadeh, K., Mohammadi, A. (2020): Measurement and simulation of the water flow and root uptake in soil under subsurface drip irrigation of apple tree. - Iranian Journal of Irrigation and Drainage 13(6): 1806-1809.

[47] Ning, S., Shi, J., Zuo, Q., Wang, S., Ben-Gal, A. (2015): Generalization of the root length density distribution of cotton under film mulched drip irrigation. - Field Crops Research 177: 125-136.

[48] Ning, S., Zhou, B., Shi, J., Wang, Q. (2021): Soil water/salt balance and water productivity of typical irrigation schedules for cotton under film mulched drip irrigation in northern Xinjiang. - Agricultural Water Management 245: 106651.

[49] Nouri, H., Stokvis, B., Galindo, A., Blatchford, M., Hoekstra, A. Y. (2019): Water scarcity alleviation through water footprint reduction in agriculture: the effect of soil mulching and drip irrigation. - Science of the Total Environment 653: 241-252.

[50] Ospanbayev, Z., Kurmanbayeva, M., Abdukadirova, Z., Doszhanova, A., Nazarbekova, S., Inelova, Z., Ablaikhanova, N., Kenenbayev, S., Musina, A. (2017): Water use efficiency of rice and soybean under drip irrigation with mulch in the south-east of Kazakhstan. - Applied Ecology and Environmental Research 15: 1581-1603.

[51] Philip, J. R. (1968): Steady infiltration from buried point sources and spherical cavities. Water Resources Research 4: 1039-1047.

[52] Phogat, V., Pitt, T., Stevens, R. M., Cox, J. W., Šimůnek, J., Petrie, P. R. (2020): Assessing the role of rainfall redirection techniques for arresting the land degradation under drip irrigated grapevines. - Journal of Hydrology 587: 125000.

[53] Qin, S., Li, S., Kang, S., Du, T., Tong, L., Ding, R. (2016): Can the drip irrigation under film mulch reduce crop evapotranspiration and save water under the sufficient irrigation condition? - Agricultural Water Management 177: 128-137.

[54] Rahneshan, Z., Nasibi, F., Moghadam, A. A. (2018): Effects of salinity stress on some growth, physiological, biochemical parameters and nutrients in two pistachio (Pistacia vera L.) rootstocks. - Journal of Plant Interactions 13(1): 73-82.

[55] Ramoliya, P. J., Pandey, A. N. (2002): Effect of increasing salt concentration on emergence, growth and survival of seedling of Salvadora oleoides (Salvadoraceae). Journal of Arid Environments 51: 121-132.

[56] Ramos, T. B., Šimůnek, J., Gonçalves, M. C., Martins, J. C., Prazeres, A., Castanheira, N. L., Pereira, L. S. (2011): Field evaluation of a multicomponent solute transport model in soils irrigated with saline waters. - Journal of Hydrology 407(1-4): 129-144.

[57] Saxena, C. K., Singh, R., Pyasi, S. K., Mekale, A. K. (2018): Evaluation of movement of wetting front under surface point source of drip irrigation in vertisols. - Journal of Agricultural Engineering 55(2): 61-67.

[58] Scognamiglio, S., De Mascellis, R., Santos, F. M., Autovino, D., Dragonetti, G., Orefice, N., Basile, A. (2019): Coupling geophysical measurements and hydrological modeling for the determination of longitudinal dispersivity. - In 2019 IEEE International Workshop on Metrology for Agriculture and Forestry (MetroAgriFor): 212-216.

[59] Shan, G., Sun, Y., Zhou, H., Lammers, P. S., Grantz, D. A., Xue, X., Wang, Z. (2019): A horizontal mobile dielectric sensor to assess dynamic soil water content and flows: direct measurements under drip irrigation compared with HYDRUS-2D model simulation. Biosystems Engineering 179: 13-21.

[60] Sharif, I., Aleem, S., Farooq, J., Rizwan, M., Younas, A., Sarwar, G., Chohan, S. M. (2019): Salinity stress in cotton: effects, mechanism of tolerance and its management strategies. - Physiology and Molecular Biology of Plants 25(4): 807-820.

[61] Shiri, J., Karimi, B., Karimi, N., Kazemi, M. H., Karimi, S. (2020): Simulating wetting front dimensions of drip irrigation systems: multi criteria assessment of soft computing models. - Journal of Hydrology 585: 124792.

[62] Šimůnek, J., van Genuchten, M. T., Šejna, M. (2008): Development and applications of the HYDRUS and STANMOD software packages and related codes. - Vadose Zone Journal 7(2): 587-600. 
[63] Srinet, R., Nandy, S., Patel, N. R. (2019): Estimating leaf area index and light extinction coefficient using Random Forest regression algorithm in a tropical moist deciduous forest, India. - Ecological Informatics 52: 94-102.

[64] Su, L., Wang, Q., Wang, C., Shan, Y. (2015): Simulation models of leaf area index and yield for cotton grown with different soil conditioners. - PloS One 10(11): e0141835.

[65] Sun, S. M., Cai, H. J., An, Q. X. (2009a): Research of salt tolerance in cotton on seeding in Alaer Xinjiang Province. - Yellow River 31(4): 81-82 (in Chinese with an English abstract).

[66] Sun, Z. J., Li, L. H., Zhang, W., Zhang, X. W., Yang, Z. P., Chang, S. W. (2009b): Research on early warning value of salt tolerance of cotton with drip irrigation under mulch. - Agricultural Research in the Arid Areas 27(4): 140-145 (in Chinese with an English abstract).

[67] Tan, S., Wang, Q., Zhang, J., Chen, Y., Shan, Y., Xu, D. (2018): Performance of AquaCrop model for cotton growth simulation under film-mulched drip irrigation in southern Xinjiang, China. - Agricultural Water Management 196: 99-113.

[68] Wang, J., Chen, R. (2020): An improved finite element model for the hydraulic analysis of drip irrigation subunits considering local emitter head loss. - Irrigation Science 38(2): $147-162$.

[69] Wang, J. S., Wang, Y. (2006): Effect of dry seeding and wet budding of cotton with drip irrigation under plastic film. - Journal of Tarim University 18(1): 77-79 (in Chinese with an English abstract).

[70] Wang, C. X., Wang, Q. J., Liu, J. J., Zhuang, L., Zhen, X. (2010): Effects of mineralization of irrigation water and soil salinity on cotton emergence rate in Southern Xinjiang Uygur Autonomous Region of China. - Transactions of the CSAE 26(9): 28-33 (in Chinese with an English abstract).

[71] Wang, Z. M., Jin, M. G., Šimůnek, J., van Genuchten, T. (2012): Evaluation of mulched drip irrigation for cotton in arid Northwest China. - Irrigation Science 32(1): 15-27.

[72] Warrick, A. W. (1974): Time-dependent linearized infiltration: I. Point sources. - Soil Science Society of America Journal 38: 383-386.

[73] Wei, C. Z., Ma, F. Y., Lei, Y. W., Li, J. H., Ye, J., Zhang, F. S. (2002): Study on cotton root development and spatial distribution under film mulch and drip irrigation. - Cotton Science 14(4): 209-214 (in Chinese with an English abstract).

[74] Xie, X., Machikowa, T., Wonprasaid, S. (2020): Drip irrigation systems controlled by soil moisture sensors and a soil water balance model for cassava grown in soils of two different textures. - South African Journal of Plant and Soil 37(4): 255-264.

[75] Yuan, X., Bai, J., Li, L., Kurban, A., De Maeyer, P. (2019): Modeling the effects of drip irrigation under plastic mulch on vapor and energy fluxes in oasis agroecosystems, Xinjiang, China. - Agricultural and Forest Meteorology 265: 435-442.

[76] Zhang, Y. L., Wang, F. X., Shock, C. C., Yang, K. J., Kang, S. Z., Qin, J. T., Li, S. E. (2017): Influence of different plastic film mulches and wetted soil percentages on potato grown under drip irrigation. - Agricultural Water Management 180: 160-171.

[77] Zhang, Y. L., Feng, S. Y., Wang, F. X., Binley, A. (2018): Simulation of soil water flow and heat transport in drip irrigated potato field with raised beds and full plastic-film mulch in a semiarid area. - Agricultural Water Management 209: 178-187.

[78] Zhao, Y., Zhai, X., Wang, Z., Li, H., Jiang, R., Hill, R. L., Si, B., Hao, F. (2018): Simulation of soil water and heat flow in ridge cultivation with plastic film mulching system on the Chinese Loess Plateau. - Agricultural Water Management 202: 99-112.

[79] Zong, R., Wang, Z., Wu, Q., Guo, L., Lin, H. (2020): Characteristics of carbon emissions in cotton fields under mulched drip irrigation. - Agricultural Water Management 231: 105992. 